\title{
Identifying Aggregate Supply and Demand Shocks in South Africa
}

Stan du Plessis, Ben Smit, and Federico Sturzenegger

CID Working Paper No. 164

May 2008

(C) Copyright 2008 Stan du Plessis, Ben Smit, Federico Sturzenegger and the President and Fellows of Harvard College
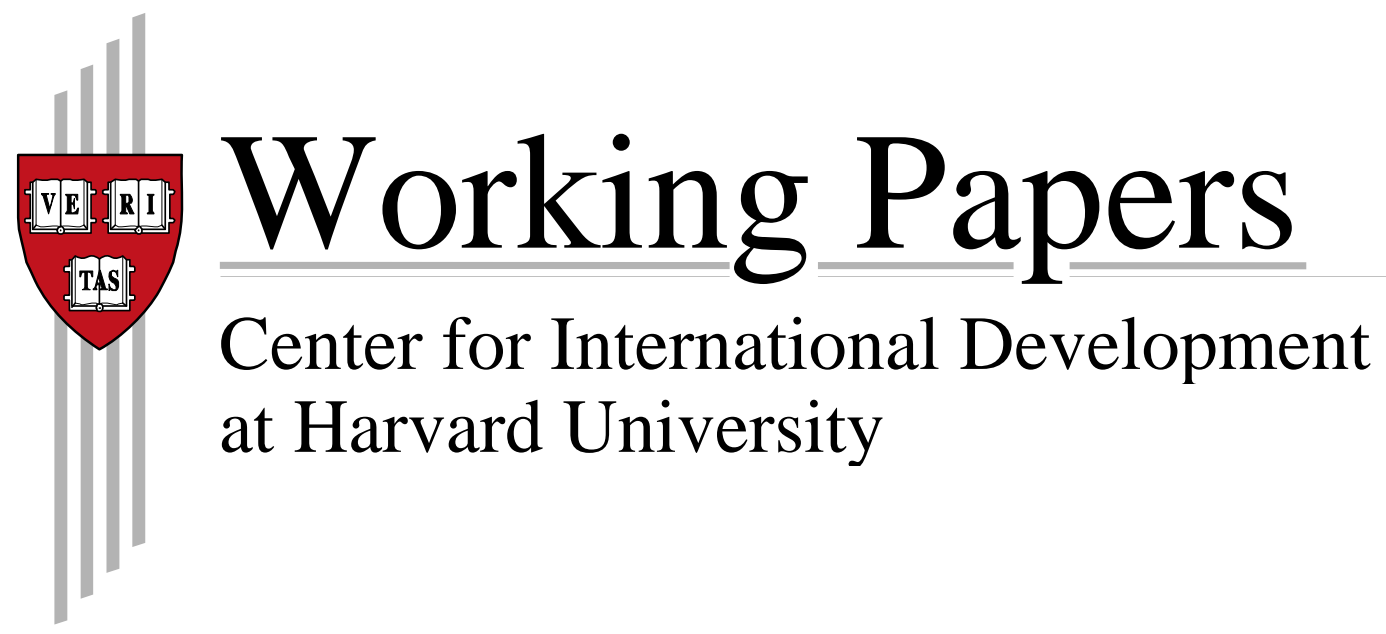


\title{
Identifying Aggregate Supply and Demand Shocks in South Africa
}

Stan du Plessis, Ben Smit, and Federico Sturzenegger

May 2008

\begin{abstract}
This paper uses a structural VAR methodology to identify aggregate demand and supply shocks to real output for the South African economy. Demand shocks, in turn, are separated into fiscal and monetary shocks. The model is estimated with quarterly data over two overlapping samples: 1960Q2 - 2006Q4 and 1983Q4 - 2006Q4. The identified (structural) shocks were used in a historical decomposition to split output into a measure of potential output (resulting from the evolution of supply shocks) and a measure of the business cycle (the gap between actual and potential output). This measure of potential output suggests a significant decline relative to trend in the years prior to the political transition of 1994 and a swift reversal thereafter. The paper presents evidence from three sources to support its identification of aggregate supply and demand shocks. These sources are the following: theory consistent impulse response functions; a close match between the implied measure of the business cycle and independent information about the South African business cycle; and a demonstration of the close match between the identified series of aggregate supply shocks and important historical events in the decades prior to and following 1994 that have been identified by economic historians as important shocks to the South African economy.
\end{abstract}

Keywords: South Africa, aggregate supply, aggregate demand, monetary policy, fiscal policy, potential output, long-run restrictions

JEL Codes: C25, C41, E32

This paper is part of the CID South Africa Growth Initiative. This project is an initiative of the National Treasury of the Republic of South Africa within the government's Accelerated and Shared Growth Initiative (ASGI-SA), which seeks to consolidate the gains of post-transition economic stability and accelerate growth in order to create employment and improve the livelihoods of all South Africans. For more information and the entire series of papers, visit the project's web site at http://www.cid.harvard.edu/southafrica. 


\title{
IDENTIFYING AGGREGATE SUPPLY
}

\author{
AND DEMAND SHOCKS IN SOUTH
}

\author{
AFRICA
}

\author{
STAN DU PLESSIS*, BEN SMIT* FEDERICO STURZENEGGER ${ }^{* * 1}$
}

July 2007

\begin{abstract}
A bstract
This paper uses a structural VAR methodology to identify aggregate demand and supply shocks to real output for the South African economy. Demand shocks, in turn, are separated into fiscal and monetary shocks. The model is estimated with quarterly data over two overlapping samples: 1960Q2-2006Q4 and 1983Q4-2006Q4. The identified (structural) shocks were used in a historical decomposition to split output into a measure of potential output (resulting from the evolution of supply shocks) and a measure of the business cycle (the gap between actual and potential output). This measure of potential output suggests a significant decline relative to trend in the years prior to the political transition of 1994 and a swift reversal thereafter. The paper presents evidence from three sources to support its identification of aggregate supply and demand shocks. These sources are the following: theory consistent impulse response functions; a close match between the implied measure of the business cycle and independent information about the South African business cycle; and a demonstration of the close match between the identified series of aggregate supply shocks and important historical events in the decades prior to and following 1994 that have been identified by economic historians as important shocks to the South African economy.
\end{abstract}

\section{JEL Codes: C25; C41; E32}

Key words: South Africa, aggregate supply, aggregate demand, monetary policy, fiscal policy, potential output, long-run restrictions

* Department of Economics, University of Stellenbosch

** Kennedy School of Government, Harvard University and Universidad Torcuato Di Tella

\footnotetext{
${ }^{1}$ We thank participants at a University of Stellenbosch retreat which took place in January 2007. This research is part of the joint initiative of the South African government and Harvard University to unveil the constraints on the growth process in South Africa. The authors would like to thank Pablo Gluzman for his invaluable research assistance.
} 
This paper offers a decomposition of output fluctuations into aggregate demand and aggregate supply shocks in South Africa for the period since the early 1960s. Theoretically motivated long-run restrictions are used to identify these shocks in a three-variable vector-autoregressive (VAR) model. The aggregate demand shocks, assumed to be transitory in nature, provide a new measure of the business cycle, whereas the cumulative aggregate supply shocks, assumed to have a long lasting effect on output, provide a novel estimate of potential output.

The research is motivated by the South African government's ongoing attempts to identify constraints to economic growth with the goal of raising the sustainable rate of growth of the economy and employment creation. As such, it contributes to the literature on quantifying measures of both potential GDP and, by implication, to studies of the business cycle in South Africa. The overlapping interests of researchers in potential GDP and the business cycle are evident from the attention given to potentially pro-cyclical macroeconomic policy in the Harvard-based Center for International Development's (CID) project to study opportunities for accelerated growth in South Africa (Frankel, Smit and Sturzenegger, 2007).

The first section of the paper is a brief introduction to the South African literature on measuring potential GDP. This is followed by an exposition of the structural VAR method used to identify the various shocks to output. Section three describes the data used and section four follows with the empirical results. 


\section{LITERATURE}

With the notable exception of De Jager and Smal (1984), the empirical literature on potential GDP in South Africa is fairly recent. Many of these studies compare different methods making it difficult to classify the South African literature according to method, as is done in many of the international surveys, for example, DuPasquier, Guay and StAmant (1999).

The focus of the literature has, however, been on contrasting univariate statistical techniques, notably the Hodrick-Prescott (HP) filter, with structural production function methods ${ }^{2}$. Production function models in this literature generally rely on a Cobb-Douglas functional form (though Smit and Burrows (2002) also estimate a CES functional form). It is expected that the univariate statistical filters will generate potential GDP growth rates close to the observed experience for a given period, but it is striking that the production function models yield very similar estimates of potential GDP.

While the comparative studies have indicated considerable agreement across methods in the estimates of potential GDP for given historical intervals in South Africa, the empirical macroeconomic literature that uses potential GDP to generate output gaps has, predominantly used the Hodrick-Prescott filter to identify potential GDP. Examples of these include: Kaseeram, Nicola and Mainardi (2004), Burger and Marinkov (2006), Geldenhuys and Marinkov (2006), Woglom (2005), Knedlik (2006), and Fedderke and Schaling (2005).

\footnotetext{
${ }^{2}$ Examples include: Smit and Burrows (2002), Arora and Bhundia (2003), Du Toit and Moolman (2003), Akinboade (2005), and Du Toit, Van Eyden and Ground (2006)
} 


\section{IDENTIFYING AGGREGATE SUPPLY AND DEMAND SHOCKS: AN}

\section{SVAR ANALYSIS}

The influential literature, starting with Shapiro and Watson (1988) and Blanchard and Quah (1989), uses long-run restrictions based on neutrality properties in the theory of macroeconomic dynamics to identify permanent and transitory shocks to real output. While Blanchard and Quah (1989) interpreted the permanent shocks as aggregate supply shocks and the transitory shocks as aggregate demand shocks, the technique has since become widely used to generate joint estimates of potential GDP (the cumulative aggregate supply shock) and a measure of business cycle fluctuations relative to GDP (the cumulative aggregate demand shock) (DuPasquier et al., 1999).

Blanchard and Quah (1989) identified these shocks in a bivariate vector-autoregressive (VAR) model assumed to have one unit root (in real GDP) and a covariance stationary variable (the rate of unemployment). This model can be extended in various directions by adding more variables with unit roots and/or by expanding the model with covariance stationary variables. The early example of King, Plosser, Stock and Watson (1991) used both these extensions, while Galí (1992) and Clarida and Galí (1994) decomposed the demand shock into several components and kept one aggregate supply shock with a unit root. This paper follows Clarida and Galís (1994) threevariable model by explicitly combining real GDP with two demand shocks, one interpreted as a fiscal policy shock and the other as a monetary policy shock. 
The technical exposition follows Clarida and Gali (1994), and starts with the proposition that the three variables (the first difference of real GDP, the fiscal policy measure, and the monetary policy measure) are jointly determined by a simultaneous equation system which can be represented by a covariance stationary MA representation such as equation 1 , $x_{t}=C(L) \varepsilon_{t}$

where

$x_{t}=\left[\begin{array}{c}\Delta y_{t} \\ g_{t} \\ r_{t}\end{array}\right], \varepsilon_{t}=\left[\begin{array}{l}\varepsilon_{1 t} \\ \varepsilon_{2 t} \\ \varepsilon_{3 t}\end{array}\right]$

where $\left\{\mathrm{y}_{\mathrm{t}}, \mathrm{g}_{\mathrm{t}}, \mathrm{r}_{\mathrm{t}}\right\}$ refers to $(\mathrm{log})$ real GDP, the fiscal policy measure, and the real interest rate respectively and $\varepsilon_{t}$ \} are the structural shocks identified with each of these variables. But this system (equation 1) is not observable and cannot be estimated. Instead we can estimate a reduced form VAR with the MA representation shown in equation 2:

$x_{t}=R(L) u_{t}$ where

$u_{t}=\left[\begin{array}{l}u_{1 t} \\ u_{2 t} \\ u_{3 t}\end{array}\right]$

where $\left\{u_{t}\right\}$ are the reduced form disturbances. The variance covariance matrix is given in equation 3:

$\Sigma=E u_{t} u_{t}^{\prime}$ 
Assume that a non-singular matrix $S$ exists such that $u_{t}=S \varepsilon_{t}$. which implies that $C(L)=$ $\mathrm{R}(\mathrm{L}) \mathrm{S}$. Keep in mind that by construction $\mathrm{R}(0)=\mathrm{I}$, which means that $\mathrm{C}(0)=\mathrm{S}$.

After normalising the elements of $\left\{\varepsilon_{\mathrm{t}}\right\}$ so that their variance covariance is the identity matrix, it follows that equation 3 can be written as:

$\Sigma=E\left(u u^{\prime}\right)=E\left(S \varepsilon \varepsilon^{\prime} S^{\prime}\right)=S S^{\prime}=C_{0} C_{0}^{\prime}$

where $C_{0}$ is the $(3 \times 3)$ matrix of contemporaneous structural relationships. Because equation 4 provides only six independent equations, three additional restrictions are required in order to estimate the full matrix and identify the nine elements of $\mathrm{C}_{0}$. Once this matrix has been computed, identification of the structural shocks $\left\{\varepsilon_{\mathrm{t}}\right\}$ follows directly from inverting the relationship $\mathrm{u}=\mathrm{C}_{0} \varepsilon_{\mathrm{t}}$. The structural representation obtains from inverting $\mathrm{C}(\mathrm{L})=\mathrm{R}(\mathrm{L}) \mathrm{C}_{0}$.

Where do these three additional restrictions, to orthogonalise the system, come from? It was Blanchard and Quah's (1989) suggestion, that restrictions on the long-run relationship between the three variables might complete the identification scheme. In their case it required only one long-run restriction, viz. a neutrality condition that the demand shock would not affect real output in the long run. However, in the threevariable model used here, we require three additional restrictions to identify the structural shocks and the dynamics of the structural system C(L).

Define $C(1)$ as $C_{0}+C_{1}+C_{2}+\ldots$ and use this to define three additional restrictions. 
The first two of these long-run restrictions require that fiscal and monetary policy shocks have no long-run effects on real GDP, as expressed in equation 5:

$$
C_{12}(1)=C_{13}(1)=0
$$

Finally, the long-run effect of monetary policy on the stance of fiscal policy is also restricted to zero as expressed in equation 6:

$$
C_{23}(1)=0
$$

This last restriction implies that monetary shocks (that affect the real interest rate) do not have long-run effects on the level of government consumption relative to GDP, the variable we will use to measure fiscal policy. This, of course, requires strong assumptions on the preferences for public goods to be true.

These restrictions create a lower-triangular matrix $\mathrm{C}(1)$, which is sufficient to recover the dynamics of the structural system, $G, C_{2}, \ldots$ as well as the structural shocks (Clarida and Galí, 1994).

Blanchard and Quah (1989) were cautious in interpreting the resulting identified shocks as aggregate supply and demand shocks. The long-run neutrality condition is not generally sufficient to identify demand shocks, since demand shocks might (under certain conditions) have a long-run mpact on output, while aggregate supply shocks may also impact at business cycle frequencies or be short-lived. At best their identification scheme was "nearly correct" (Blanchard and Quah, 1989: 659), and the extent to which it was correct is an empirical matter. 
To investigate the plausibility of the identification scheme on the model posed here for South African data, we consider the same output as Blanchard and Quah, viz. impulse response functions and a variance decomposition analysis, a historical decomposition of the output effects of the structural shocks, and a comparison of this historical decomposition with independent information about the business cycle and factors affecting aggregate supply in South Africa.

\section{DATA}

The data are seasonally adjusted quarterly time series, starting in the second quarter of 1960 and ending in the fourth quarter of $2006^{3}$. Table 1 shows the variables used in the model and Figures 1 to 3 plot the three main variables. The reduced form VAR was estimated with four lags.

Table 1 about here

Figure 1 about here

As a further robustness check, the estimation and identification were implemented on the entire sample starting in the second quarter of 1960 and on a sub-sample starting in the fourth quarter of 1983. This check was carried out for two reasons. Firstly, the important evolution of the monetary policy regime in South Africa during the early eighties when quantitative controls were largely abandoned in favour of market-based

${ }^{3}$ The data for the fourth quarter are an estimate. 
instruments, as was recommended by the De Kock Commission (1985). Secondly, as can be seen in Figure 2, there is some doubt over the covariance stationarity ${ }^{4}$ of the fiscal policy proxy over the longer sample, a problem which is less serious in the shorter sample (the unit root tests are reported in Appendix A).

Figure 2 about here

Figure 3 about here

As a proxy for the stance of fiscal policy we use government consumption, rather than the deficit. Many other measures of the stance of fiscal policy, such as the budget balance, are jointly determined with the economic cycle and are inappropriate for the purpose at hand. Since government revenue accounts for a large portion of the joint endogeneity between the budget balance and the economic cycle, a useful proxy of the fiscal stance for purposes of judging the cyclicality of fiscal policy is the ratio of government expenditure to GDP. This is also the measure used by Fatás and Mihov (2003) to investigate the potentially destabilising role of fiscal policy in a large crosscountry study.

As a proxy for monetary policy we use the real interest rate. Alternative estimations

\footnotetext{
${ }^{4}$ Ideally all the variables in the estimated model should be covariance stationary, which implies that they must not have stochastic trends. Augmented Dickey-Fuller tests were used to test for the presence of unit roots and are reported in Appendix A.
} 
using the inflation rate itself were done, delivering comparable results which are available upon request.

\section{RESULTS}

This section reports impulse responses and historical decompositions to support the plausibility of the identified supply and demand shocks proposed here.

\subsection{Innovation accounting}

Innovation accounting entails considering the impulse responses and variance decomposition of structural VAR models. The first task is to inspect the impulse response functions of the identified shocks to determine whether they match theoretical priors concerning the direction and magnitude of impact. Figure 4 below shows the impulse responses of real GDP for each of the identified shocks and for both the longer and shorter sample models.

Figure 4 about here

The impulse responses in Figure 4 are consistent with theoretical priors. The supply shock has a permanent impact on real GDP, while the two components of aggregate demand have, by construction, only transitory impacts. A positive fiscal shock has a temporary expansionary impact on real GDP and a positive shock to the real interest rate has a temporary contractionary impact on real output. The fiscal effect is stronger in the longer sample, though that should be interpreted cautiously given the potential non-stationarity of the fiscal proxy over that sample. 
The variance decomposition of real GDP shows the proportion of the variance of real GDP which can be accounted for by the three identified shocks over various horizons. Table 2 contains the variance decomposition for real GDP, from which two deductions follow. Firstly, the long-run development of real GDP is dominated by the history of supply shocks. Secondly, over the short to medium term, fiscal shocks dominate monetary shocks in their impact on real GDP, but only in the model estimated on the longer sample. In the post-1983 sample the relative importance of monetary and fiscal policy shocks are reversed.

Figure 5 about here

This difference between the variance decompositions of the shorter and longer sample models might be due to the changing average size and variability of the three structural shocks over the sample period. Figure 5 uses box plots by decade to show how the distribution of these shocks has changed over time. The monetary policy shocks have become more dispersed since the 1960s, while the opposite seems to have happened with the GDP growth and fiscal policy shocks. A model estimated over the entire sample period therefore combines two very different periods (with a pivotal point around 1980) in the monetary history of South Africa. This stylised observation can be sensibly connected with the reforms of the monetary policy regime introduced by the De Kock commission and implemented in the course of the early to middle 1980s.

Figure 6 shows the impulse responses of the real interest rate relative to the three identified shocks for both samples. A positive supply shock raises the real interest rate 
temporarily in both samples. This is expected from the transitory disinflationary impact of a positive supply shock. A positive fiscal shock lowers the real interest rate temporarily, notably in the model estimated on the shorter sample, which suggests that over that sample a fiscal stimulus meets with accommodating monetary policy.

Figure 6 about here

Figure 7 shows the impulse response functions for government expenditure relative to the three identified shocks for both samples. The reaction of the fiscal proxy to a supply shock in both samples suggests that GDP responds faster to a positive supply shock than government expenditure. At least in the model estimated on the shorter sample, government expenditure catches up with GDP over the medium term. The positive response of a fiscal shock to a rise in the real interest rate might suggest a counteracting fiscal response to a monetary policy shock, but even at its maximum, the effect is very small and is not of great practical interest.

Figure 7 about here

\subsection{Historial decomposition}

The moving average representation of the structural system, i.e. equation 1 , can be used to decompose the historical real GDP series into paths attributable to each of the identified shocks. For example, the structural VAR can be used to plot the evolution of real GDP under the assumption that both demand shocks are zero, to yield a measure of supply shocks to GDP which, aggregated over time and added to any non-stationary 
drift, may construct an estimate of potential GDP. Similar historical decompositions can be used to plot the contribution of the two demand shocks to the time path of GDP and jointly they will yield a measure of the business cycle. Figure 8 shows the historical decomposition of real GDP into components due to supply shocks, fiscal shocks, and monetary shocks ${ }^{5}$.

Figure 8 about here

The major difference between the historical decompositions for the short and longer sample models lies in the much larger contribution of fiscal shocks to GDP in the longer sample. For example, fiscal policy has contributed positively to real GDP since about 2000 on both estimates, but much more powerfully so in the model estimated on the longer sample. However, in both models the supply shocks dominate fluctuations in real GDP.

The patterns of the cumulated supply shocks are not identical in the two models but show remarkable similarity, with both recording continued negative supply shocks from the mid-eighties through 1994, after which positive supply shocks moved actual and potential real GDP up. Figure 9 shows the estimated potential GDP for the shorter and longer samples yielded by this decomposition.

${ }^{5}$ The series for the potential output and business cycle measures are presented in Appendix B. 
Figure 9 about here

The longer sample yields an opportunity to quantify the cumulative loss in aggregate supply suffered by the South African economy in the twilight of apartheid. The top graph in figure 9 shows that the generally positive supply shocks of the sixties were reversed from 1973 onwards. Adverse international events, notably the first oil shock, but also the collapse of the Portuguese colonies (Mozambique and Angola) which created hostile states on the borders of South Africa, signalled the start of two decades of adverse supply shocks. Domestic unrest in 1976 and again in the mid-1980s, the debt standstill in 1985, and the final unravelling of the National Party's grip on political power were all along the path of declining potential GDP, most likely fuelled by significant human and capital flight.

Figure 10 matches important international events, political developments, policy decisions, and economic shocks to the cumulative supply shocks as identified by the longer sample model. On this measurement potential GDP declined by a cumulative $30 \%$ relative to trend between the mid-seventies and the mid-nineties. In this way the decomposition provides a unique quantification of the costs of maintaining apartheid since the seventies, in a time of adverse international shocks. It yields a plausible pattern and magnitude, given historical accounts of the economic costs of apartheid by Moll (1991) and Feinstein (2005), for example. 
Figure 10 about here

The new measure of potential GDP also shows a marked rise in potential GDP since 1994, starting almost immediately after the political transition. While the pattern differs for the models estimated on the longer and shorter samples (the longer sample model shows a sharper bounce in potential GDP immediately after the political transition which flattens out after 2000, while the shorter sample model shows a slower initial response for potential GDP but an acceleration after 2000), both imply that potential GDP has lately been growing at a healthy rate, though well short of the goals set by the South African government. Table 3 shows the growth rate of potential GDP for the two models calculated over different sub-samples of the post-1994 era. The estimates in Table 3 suggest a range of $2.5 \%$ to $4.4 \%$ for the growth rate of potential GDP, while 3.5\% would be a likely point estimate (Frankel et al., 2007: 14).

Table 3 about here

In addition to examining the plausibility of the identified supply shocks, one might also examine the plausibility of the identified demand shocks through comparison with independent information on the South African business cycle. Following Blanchard and Quah (1989), we compare the cumulative aggregate demand shock with the turning points of the South African business cycle as identified by (i) the dating committee of the SARB, and (ii) the turning points identified by Du Plessis (2006) using a nonparametric dating algorithm applied to real GDP. Figure 11 shows the phases of the business cycle defined with these two methods and the new measure of aggregate 
demand is superimposed onto it

The measure of aggregate demand identified with the long-run restrictions matches the periods of relative expansion and relative contraction in the South African economy surprisingly well. This is particularly the case where the comparison is made with $\mathrm{Du}$ Plessis' (2006) alternative turning points, which, he has argued, capture the periods of relative contraction and expansion in the South African GDP more accurately than the official turning points.

The only real anomaly in the comparison is the apparent positive demand shock during the contraction following the peak of June 1984. Du Plessis and Smit (2007) examined the circumstances of this contraction and found that it was the only post-1980 contraction in South Africa during which the monetary authorities provided a cumulatively large nominal and particularly real reduction in their policy interest rate. Not all downswings are due to demand shocks (in this case the demand shock from monetary policy was notably positive) and in this case the downswing is largely explained by a sharp negative supply shock as identified (see Figure 10). The model as presented here, is not sensitive enough to identify the precise nature of that supply shock, but Frankel, Smit and Sturzenegger (2007: 11) highlight two developments that were particularly adverse in 1984 and would have ended in the supply shock as identified here, i.e. a precipitous decline in public investment and depressed terms of trade.

Apart form this period, the new business cycle measure matches existing evidence 
closely. Following Blanchard and Quah (1989: 665), we interpret this close match between the business cycle measure, generated by the identified demand shocks, and independent business cycle information as suggestive of the plausibility of the identified demand shocks.

\section{CONCLUSION}

This paper applies a structural VAR method to identify aggregate supply and demand shocks for the South African economy since the 1960s. The impulse responses suggest that the identified structural shocks and system dynamics are theory consistent. Further, the identified aggregate supply shock is used to yield a new measure of potential GDP and of the business cycle. The new measure of potential GDP suggests that the South African economy suffered a 30\% relative decline in potential GDP between the midseventies and mid-nineties as the internal and external costs of apartheid rose at a time of distuption in the world economy. It also suggests that the present trajectory potential GDP is growing by about $2.5 \%$ to $4.4 \%$ per year with a likely value of around $3.5 \%$. This order of magnitude compares favourably with some of the more recent calculations in the literature such as Du Toit, Van Eyden and Ground (2006).

The identified demand shock was also used to create a new measure of the South African business cycle, which matched independent information about the business cycle. The plausible history of the new measures for the business cycle and potential GDP support the method of identification used here. 
Table $1 \quad$ D ata

\begin{tabular}{lll}
\hline Variable & Calculation & Source \\
\hline$\Delta y_{t}$ & First difference of the log & SARB, RB6006D \\
& of real GDP & \\
& Ratio of government & SARB, RB6008D, \\
$g_{t}$ & consumption to GDP & RB6006D \\
& Real interest rate calculated & SARB, Discount rate and \\
$r_{t}$ & using monthly data and a & CPI index, RB 7032N \\
& within-quarter formula & \\
\hline
\end{tabular}

${ }^{6}$ For each quarter the real interest rate was calculated using monthly data and the following formula where $m_{t}$ means the second month of the quarter: $\operatorname{Avg}\left(i_{m t-1}, i_{m t}, i_{m t+1}\right)-\left\{\left[\ln \left(\frac{C P I_{m t}+C P I_{m t+1}}{2}\right)-\ln \left(\frac{C P I_{m t}+C P I_{m t-1}}{2}\right)\right]^{12}-1\right\}$ 
T able 2 V arianœ decomposition of real G D P

\begin{tabular}{|c|ccc|}
\hline Quarter & \multicolumn{3}{|c|}{ Variance Decomposition of GDP } \\
$\mathrm{N}^{\mathrm{o}}$ & Supply Shock & Fiscal Shock & Monetary Shock \\
\hline 1 & $69.0 \%$ & $28.3 \%$ & $2.6 \%$ \\
2 & $67.6 \%$ & $31.4 \%$ & $1.0 \%$ \\
3 & $58.6 \%$ & $37.0 \%$ & $4.4 \%$ \\
4 & $62.2 \%$ & $35.2 \%$ & $2.6 \%$ \\
5 & $64.0 \%$ & $33.3 \%$ & $2.7 \%$ \\
6 & $63.4 \%$ & $33.6 \%$ & $2.9 \%$ \\
7 & $68.3 \%$ & $29.9 \%$ & $1.8 \%$ \\
8 & $70.0 \%$ & $28.1 \%$ & $1.9 \%$ \\
9 & $72.0 \%$ & $26.5 \%$ & $1.5 \%$ \\
10 & $74.7 \%$ & $24.2 \%$ & $1.2 \%$ \\
11 & $75.9 \%$ & $23.0 \%$ & $1.1 \%$ \\
12 & $77.6 \%$ & $21.6 \%$ & $0.9 \%$ \\
13 & $78.9 \%$ & $20.3 \%$ & $0.8 \%$ \\
14 & $80.1 \%$ & $19.3 \%$ & $0.7 \%$ \\
15 & $81.3 \%$ & $18.1 \%$ & $0.6 \%$ \\
\hline 20 & $85.9 \%$ & $13.7 \%$ & $0.3 \%$ \\
30 & $91.6 \%$ & $8.2 \%$ & $0.1 \%$ \\
50 & $96.6 \%$ & $3.4 \%$ & $0.0 \%$ \\
75 & $98.7 \%$ & $1.3 \%$ & $0.0 \%$ \\
100 & $99.5 \%$ & $0.5 \%$ & $0.0 \%$ \\
\hline
\end{tabular}

Longer sample (1960+)

\begin{tabular}{|c|ccc|}
\hline Quarter & \multicolumn{3}{|c|}{ Variance Decomposition of GDP } \\
$\mathrm{N}^{\mathrm{o}}$ & Supply Shock & Fiscal Shock & Monetary Shock \\
\hline 1 & $88.7 \%$ & $1.0 \%$ & $10.3 \%$ \\
2 & $86.0 \%$ & $5.1 \%$ & $8.9 \%$ \\
3 & $82.4 \%$ & $3.0 \%$ & $14.6 \%$ \\
4 & $88.2 \%$ & $3.7 \%$ & $8.1 \%$ \\
5 & $88.3 \%$ & $3.3 \%$ & $8.4 \%$ \\
6 & $90.9 \%$ & $2.4 \%$ & $6.7 \%$ \\
7 & $93.5 \%$ & $1.5 \%$ & $5.0 \%$ \\
8 & $94.7 \%$ & $1.2 \%$ & $4.1 \%$ \\
9 & $96.1 \%$ & $0.6 \%$ & $3.3 \%$ \\
10 & $97.3 \%$ & $0.4 \%$ & $2.3 \%$ \\
11 & $97.8 \%$ & $0.2 \%$ & $2.0 \%$ \\
12 & $98.4 \%$ & $0.1 \%$ & $1.5 \%$ \\
13 & $98.8 \%$ & $0.0 \%$ & $1.2 \%$ \\
14 & $99.0 \%$ & $0.0 \%$ & $1.0 \%$ \\
15 & $99.2 \%$ & $0.0 \%$ & $0.8 \%$ \\
\hline \hline 20 & $99.7 \%$ & $0.0 \%$ & $0.2 \%$ \\
30 & $99.9 \%$ & $0.0 \%$ & $0.0 \%$ \\
50 & $100.0 \%$ & $0.0 \%$ & $0.0 \%$ \\
75 & $100.0 \%$ & $0.0 \%$ & $0.0 \%$ \\
100 & $100.0 \%$ & $0.0 \%$ & $0.0 \%$ \\
\hline
\end{tabular}

Shorter sample (1983+) 
Table 3 G rowth rate of potential G D P during different sub-samples

\begin{tabular}{lcc}
\hline & Longer sample $(1960+)$ & Shorter sample (1983+) \\
\hline 1994Q1 to present & $3.13 \%$ & $3.32 \%$ \\
1996Q1 to present & $2.74 \%$ & $3.34 \%$ \\
1998Q1 to present & $2.82 \%$ & $3.42 \%$ \\
$2000 \mathrm{Q} 1$ to present & $2.56 \%$ & $3.58 \%$ \\
$2002 \mathrm{Q} 1$ to present & $2.62 \%$ & $4.17 \%$ \\
$2004 \mathrm{Q} 1$ to present & $2.9 \%$ & $4.4 \%$ \\
\hline
\end{tabular}

Figure 1 First difference of logged real G D P

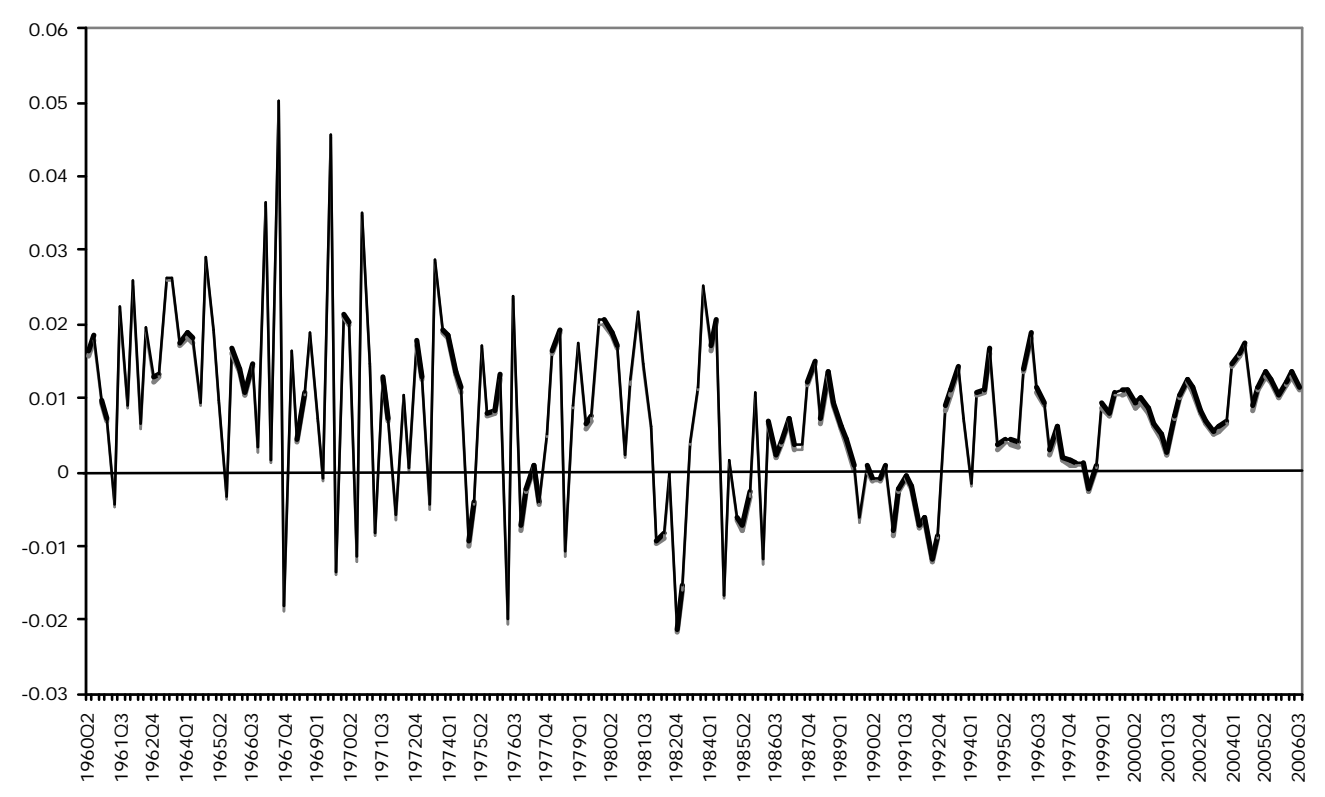


Figure 2 Ratio of government ex penditure to G D P

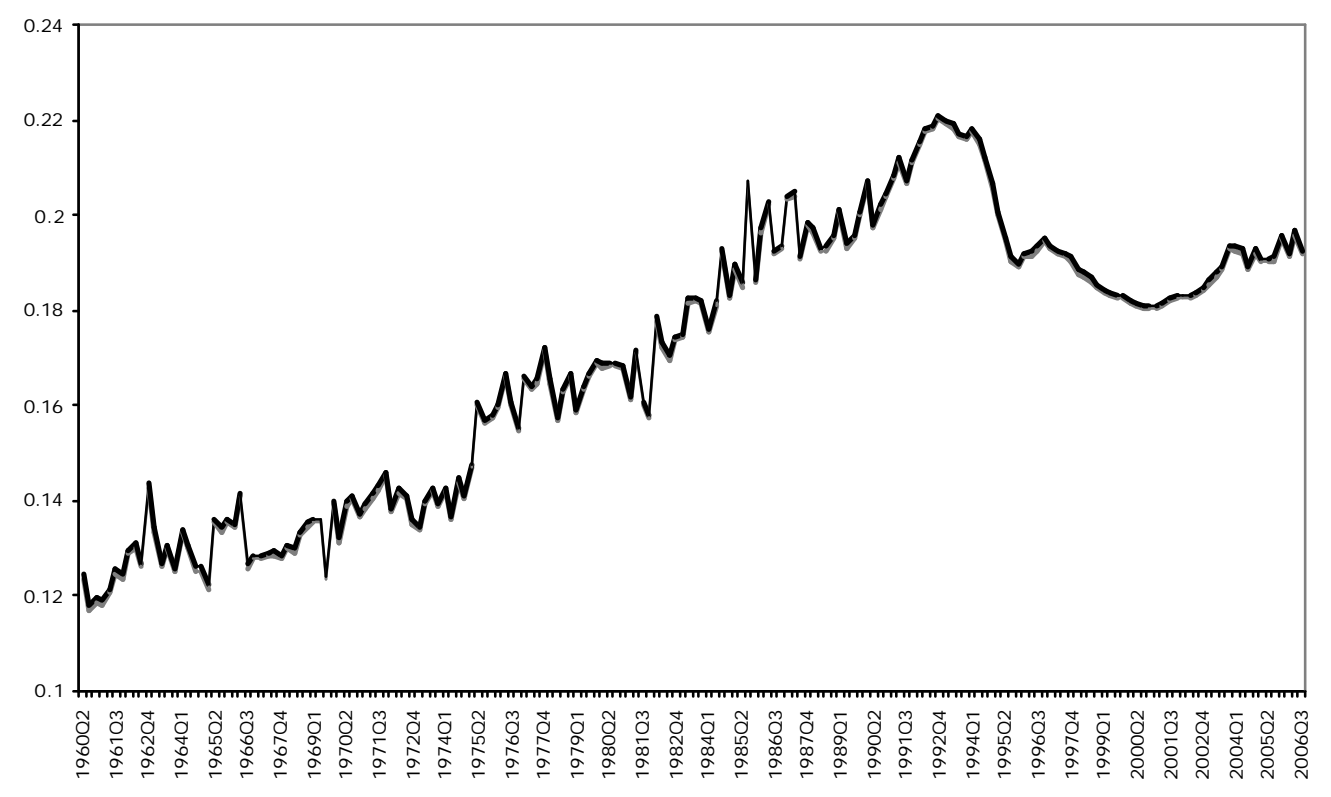


Figure 3 Real interest rate

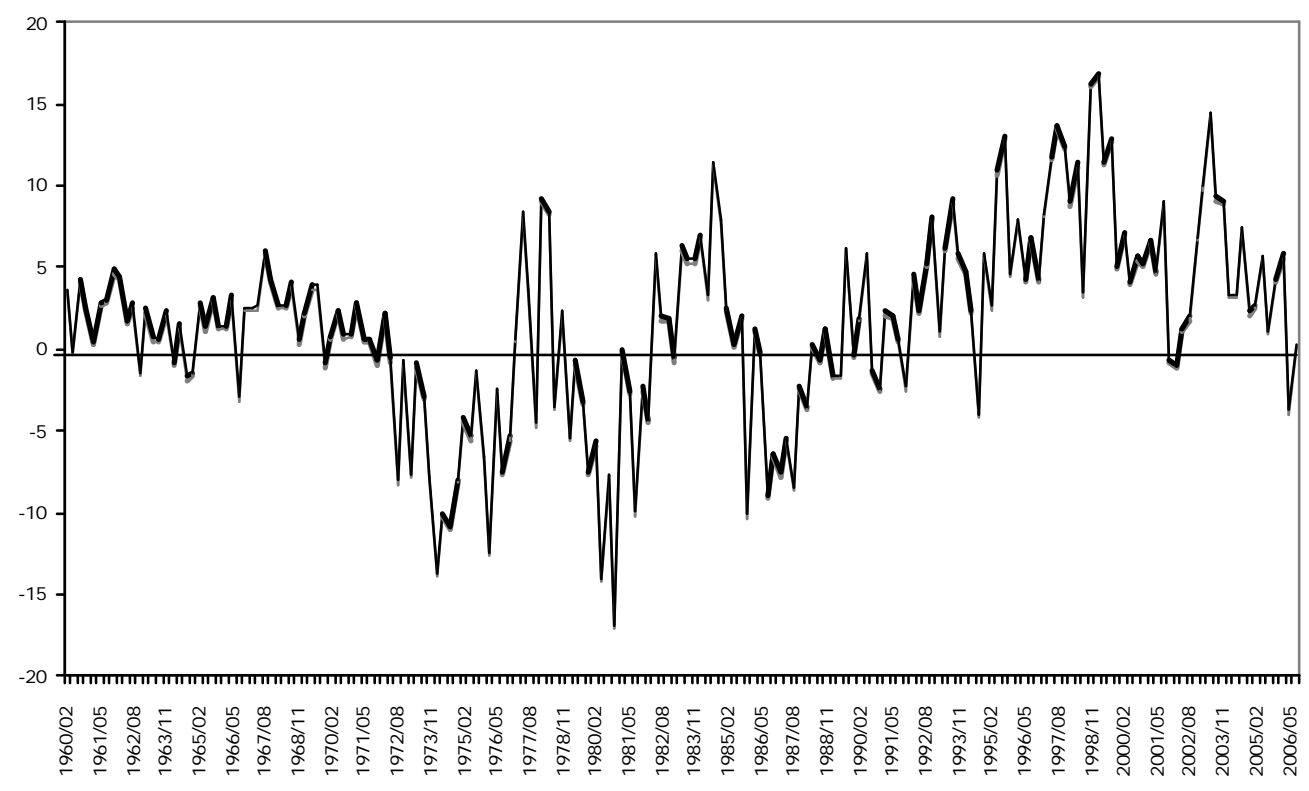


Figure 4 Impulse response of real G D P for each of the identified shocks

Longer sample (1960+)

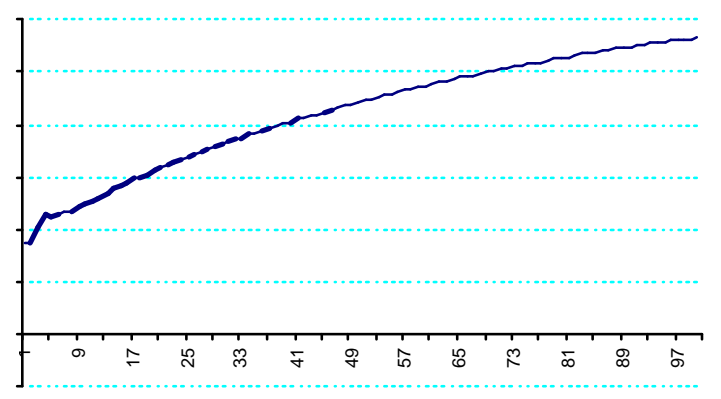

_ Accumulated Response of GDP to Supply Shock

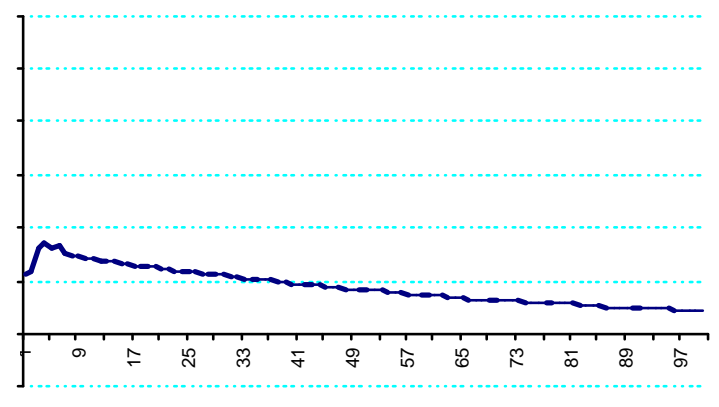

_ Accumulated Response of GDP to Fiscal Shock

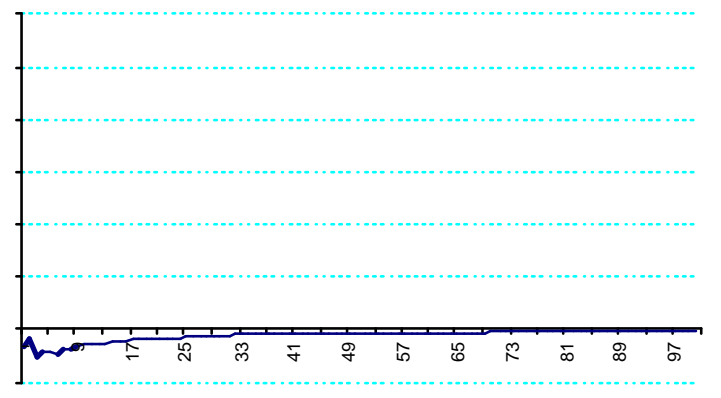

_ Accumulated Response of GDP to Monetary Shock
Shorter sample (1983+)

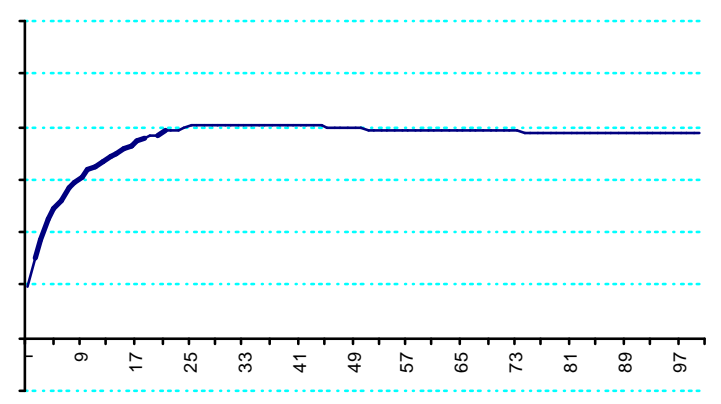

_ Accumulated Response of GDP to Supply Shock

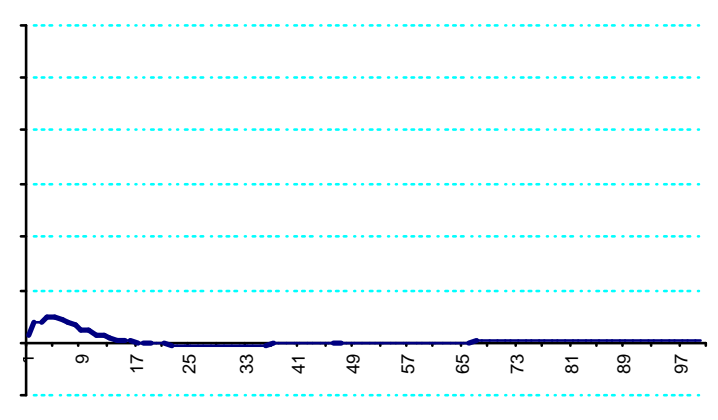

_ Accumulated Response of GDP to Fiscal Shock

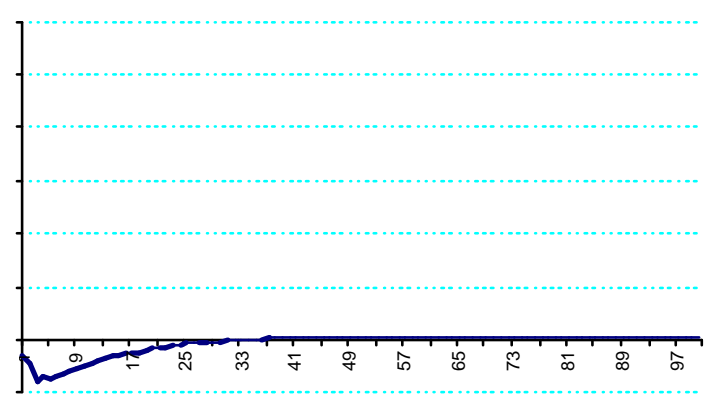

_ Accumulated Response of GDP to Monetary Shock 
Figure 5 Box plot of structural shocks to the three variables by decade

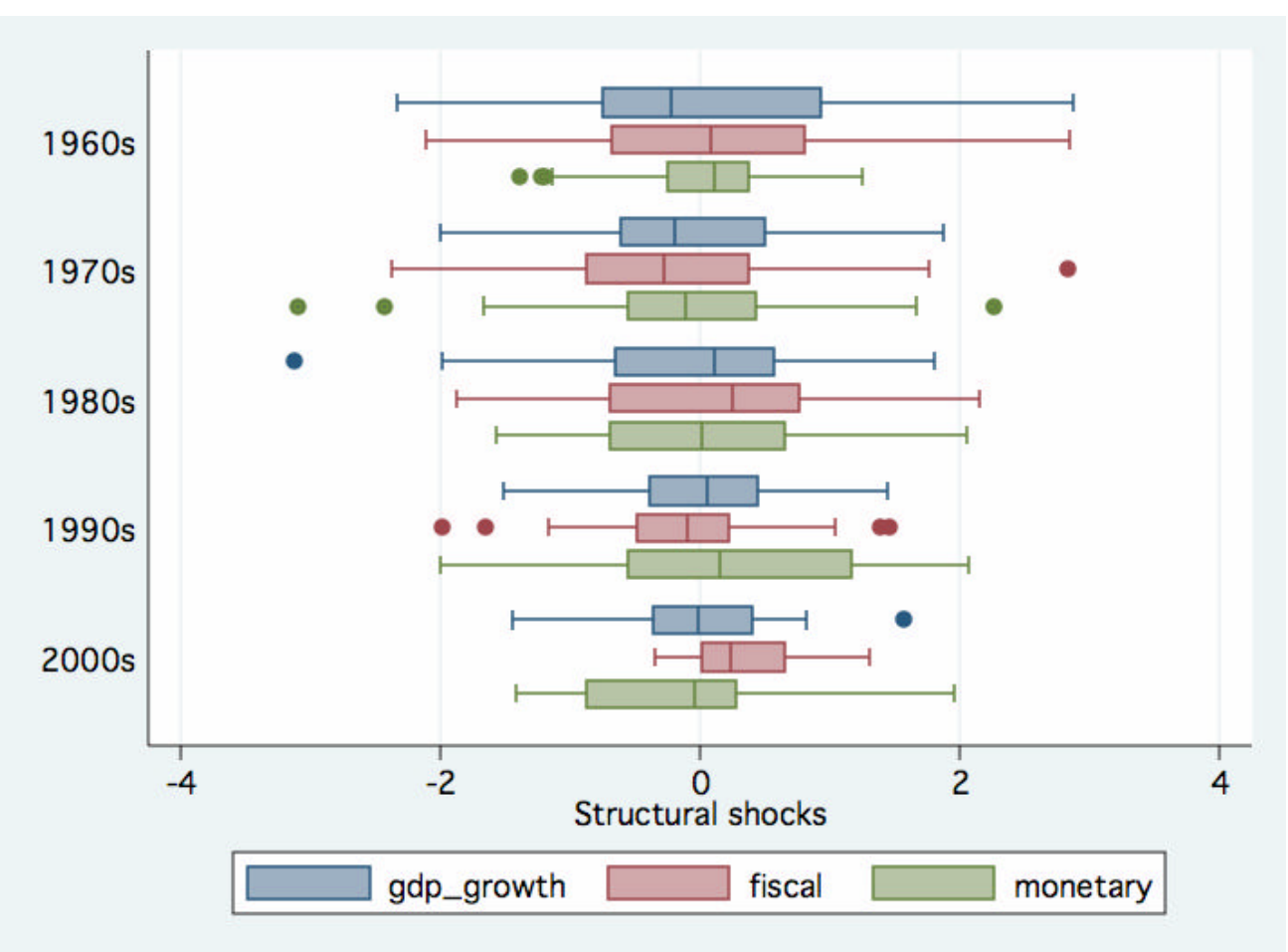


F igure 6 Impulse response of the real interest rate for each of the identified shocks

Longer sample (1960+)

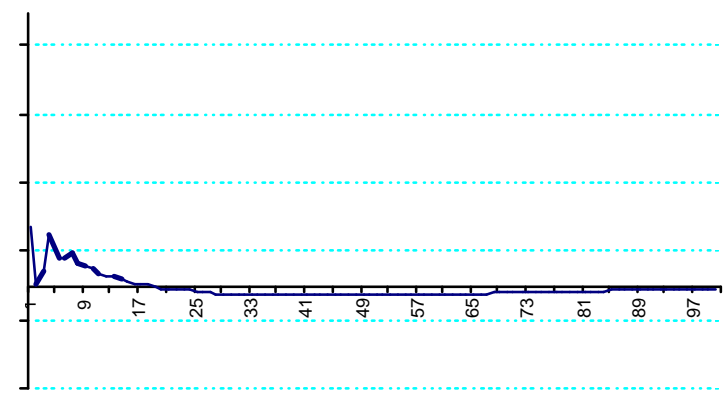

_ Response of Real hterest Rate to Supply Shock

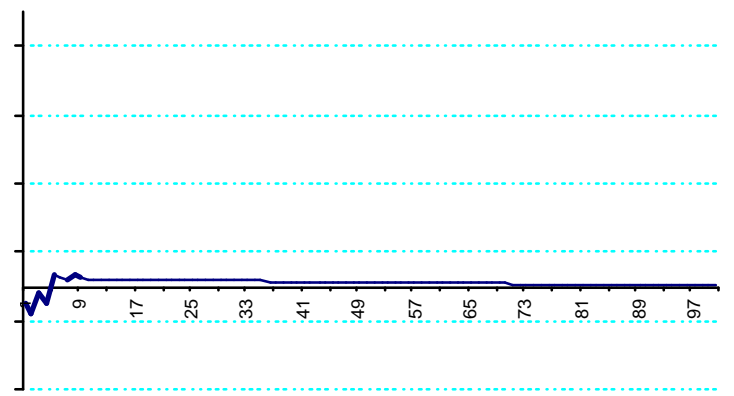

_- Response of Real Interest Rate to Fiscal Shock

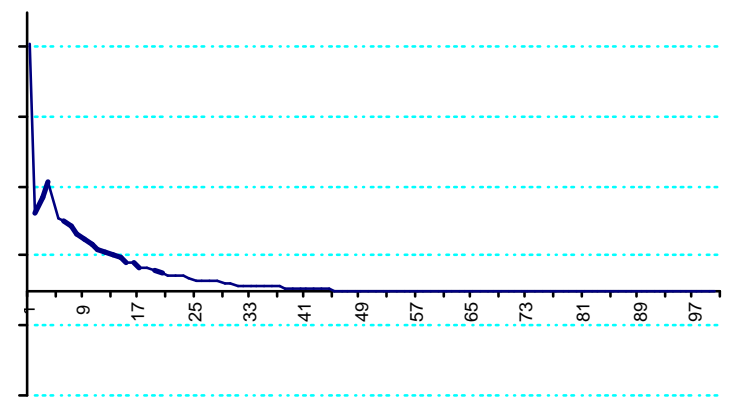

_ Response of Real Interest Rate to Monetary Shock
Shorter sample (1983+)

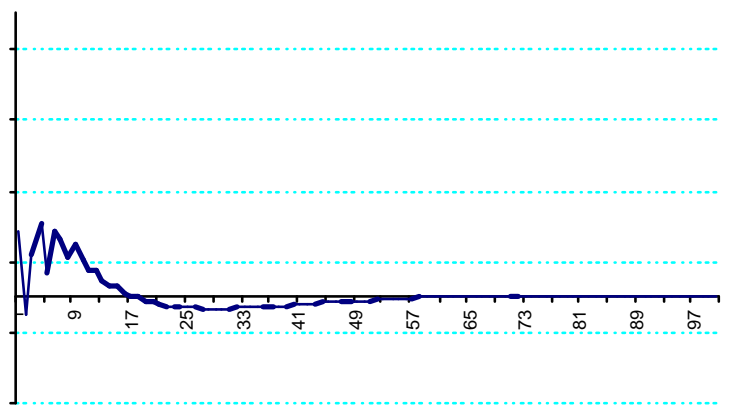

_ Response of Real Interest Rate to Supply Shock

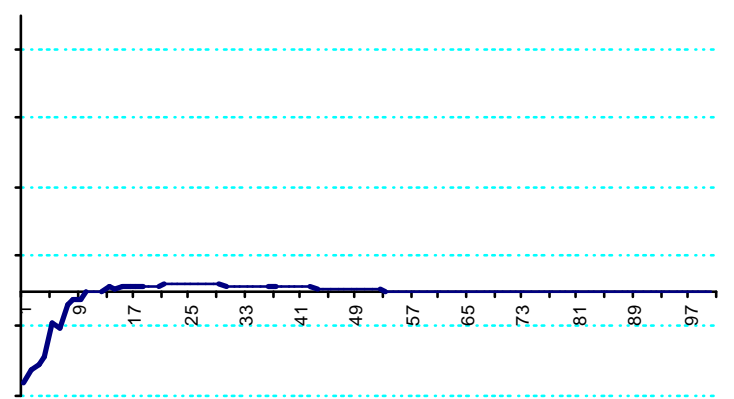

_ Response of Real Interest Rate to Fiscal Shock

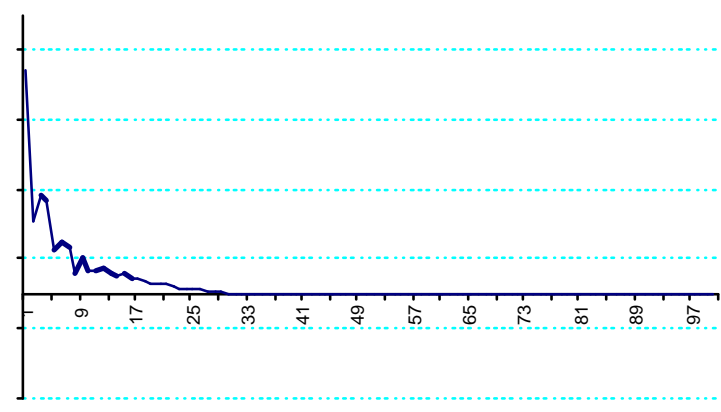

_ Response of Real Interest Rate to Monetary Shock 
Figure 7 Impulse response of government consumption to real G D P for each of the identified shocks

Longer sample (1960+)

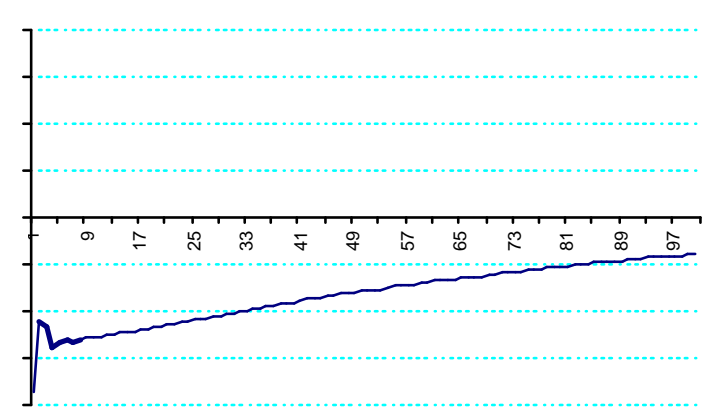

- Response of Gov. Cons. as percentage of GDP to Supply Shock

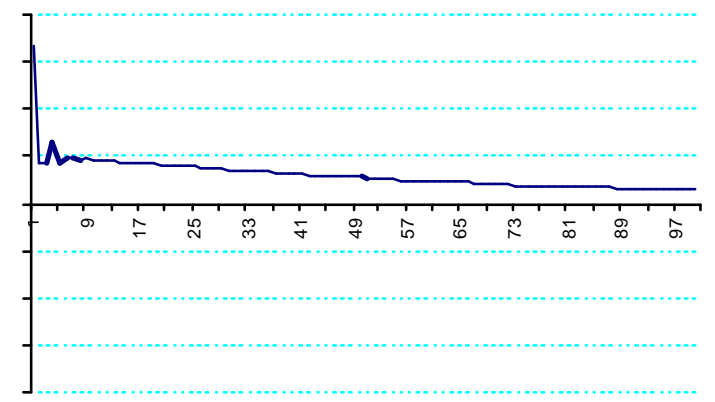

— Response of Gov. Cons. as percentage of GDP to Fiscal Shock

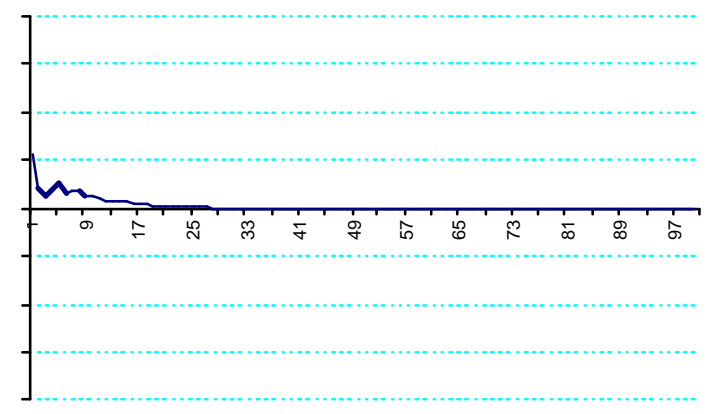

_ Response of Gov. Cons. as percentage of GDP to Monetary Shock
Shorter sample (1983+)
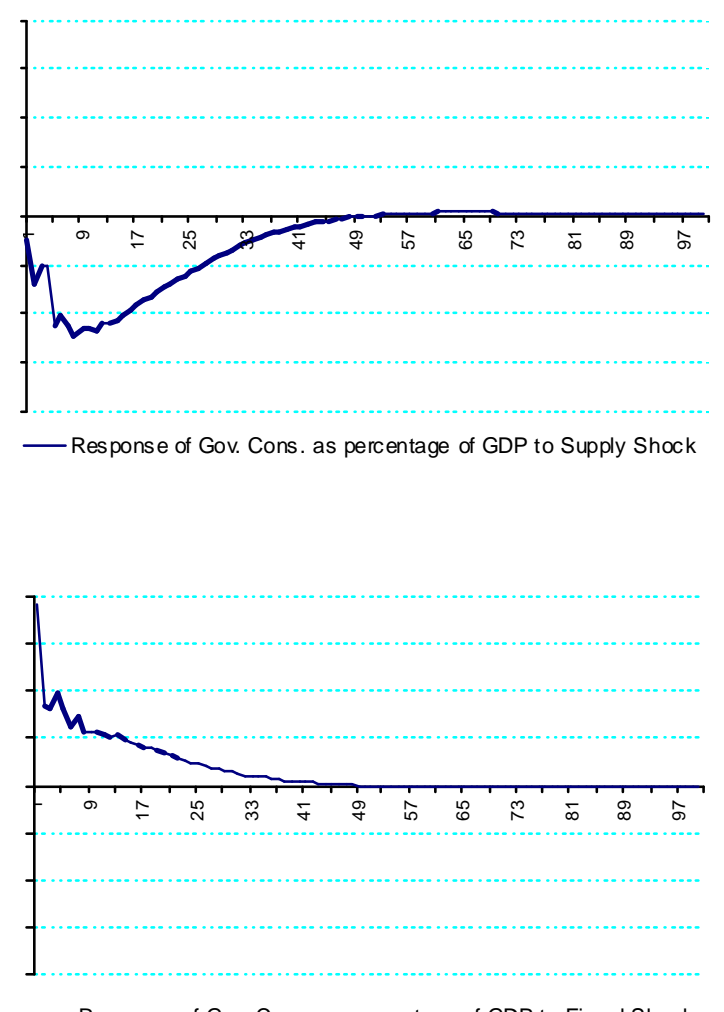

- Response of Gov. Cons. as percentage of GDP to Fiscal Shock

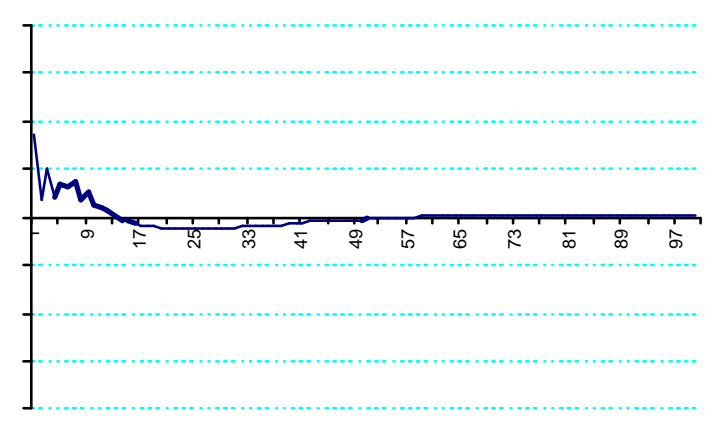

_ Response of Gov. Cons. as percentage of GDP to Monetary Shock 
Figure 8 H istorical decomposition of real G D P

Longer sample (1960+)

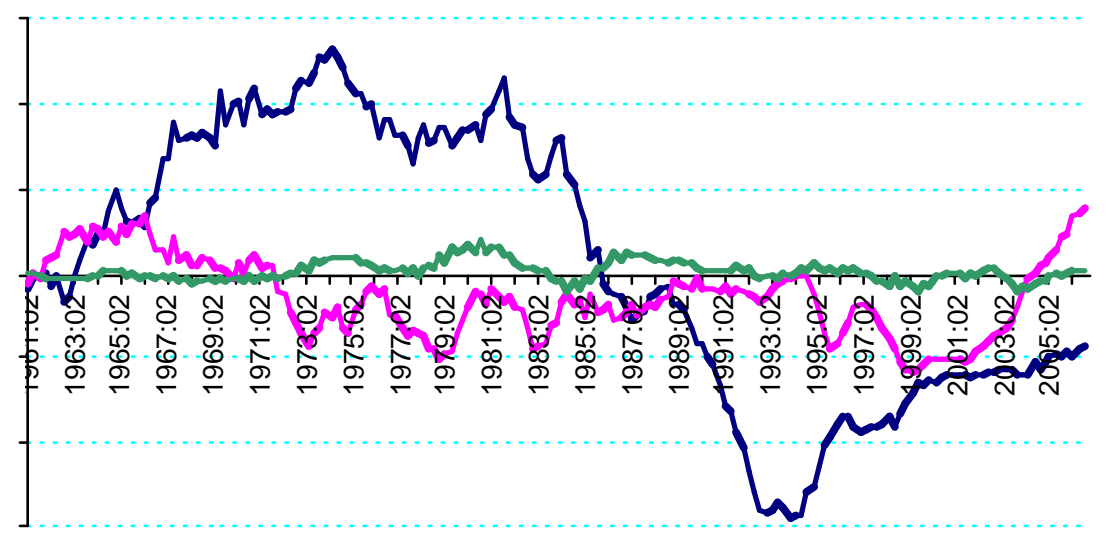

— Supply Shock — Fiscal Shock — Monetary Shock

Shorter sample (1983+)

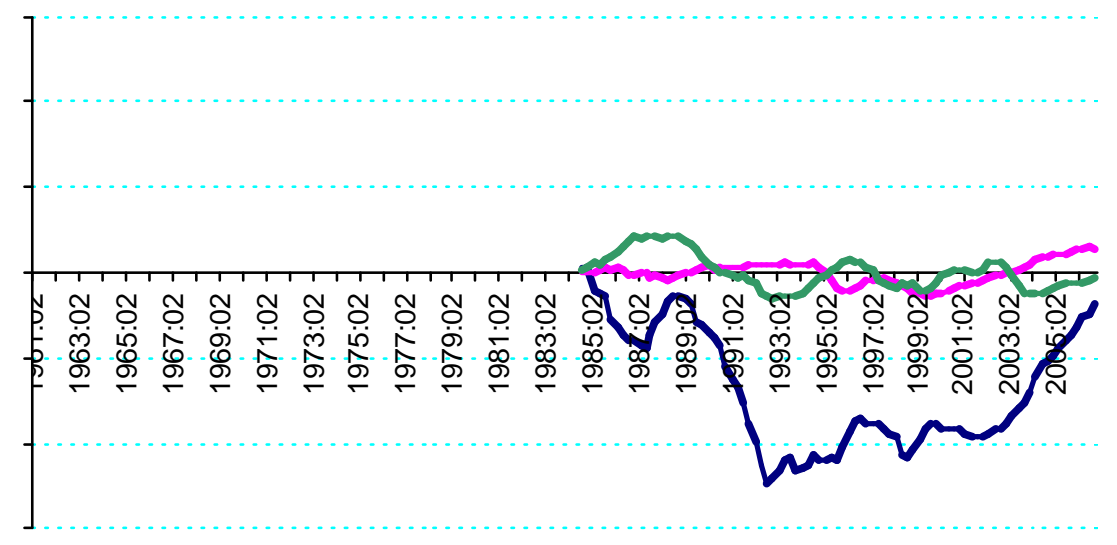

— Supply Shock _ Fiscal Shock — Monetary Shock 
Figure $9 \quad \mathrm{~N}$ ew measure of aggregate supply

Longer sample (1960+)

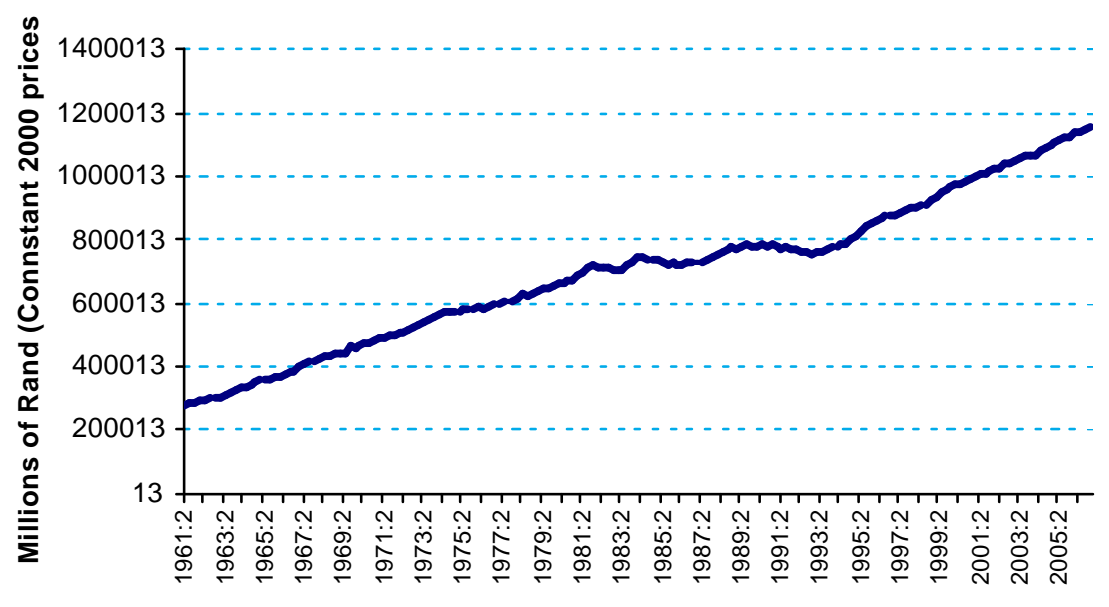

Acc. Response of GDP to Supply Shock + Forecast

Shorter sample (1983+)

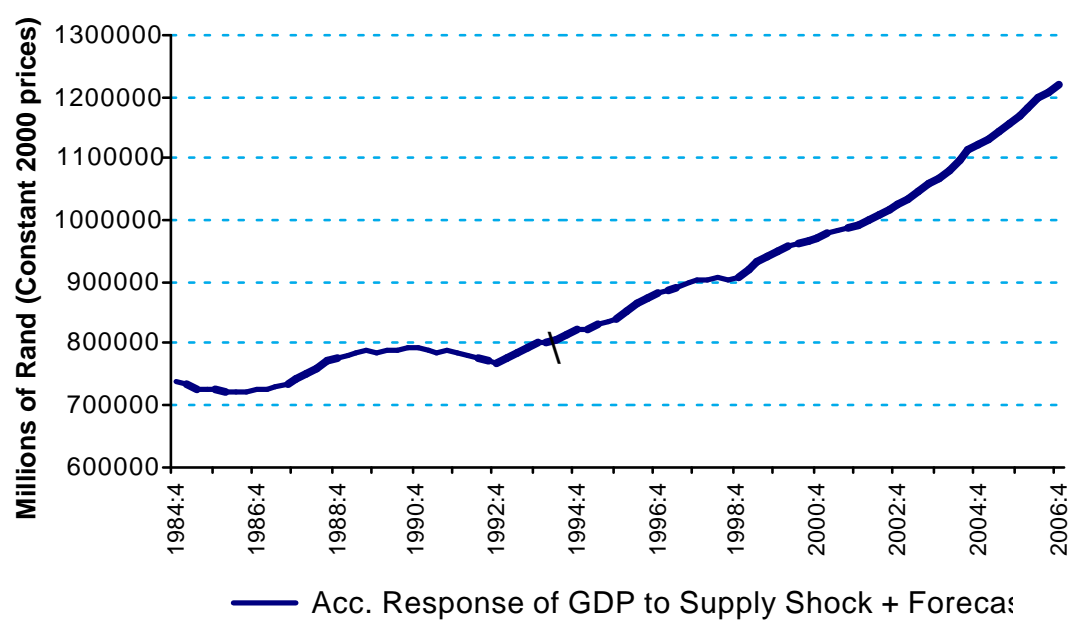


Figure 10 E vents associated with supply shodks to the South A frican economy

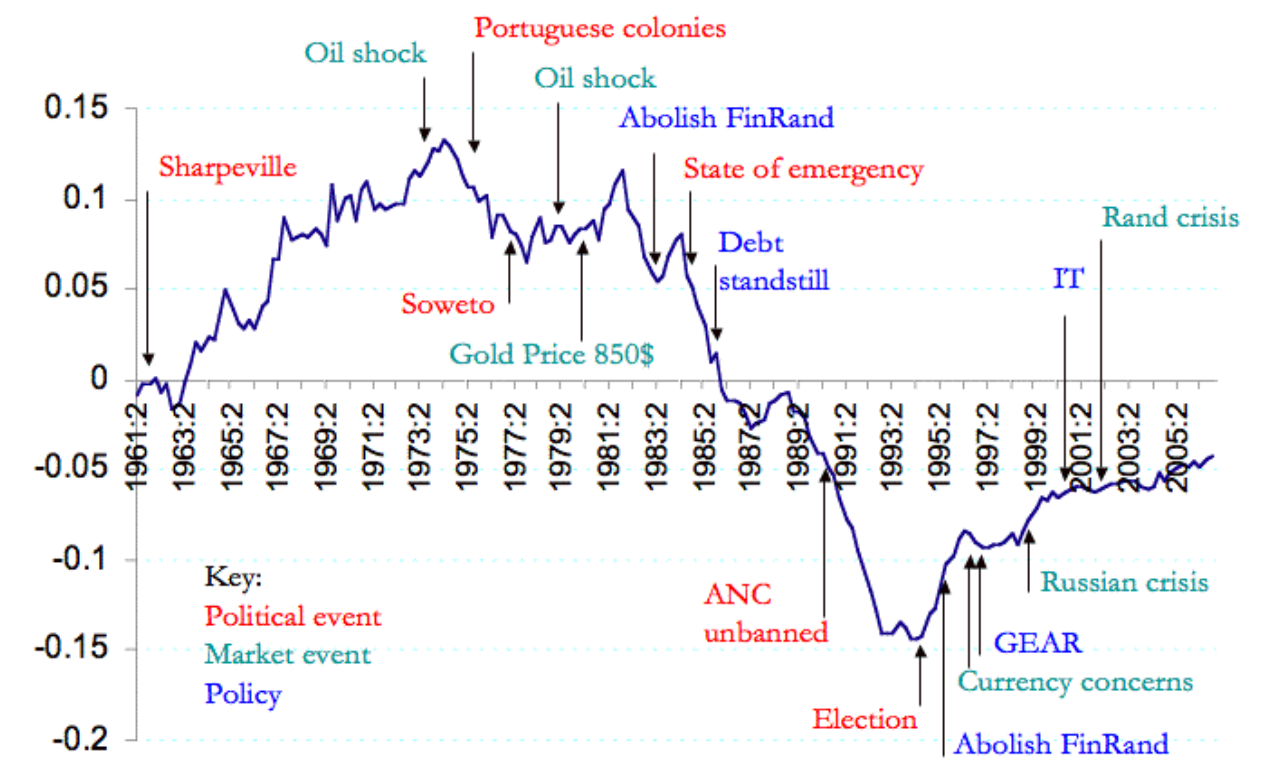

Accumulated Response of GDP to Supply Shock 
Figure $11 \mathrm{~N}$ ew measure of aggregate demand

Longer sample (1960+)

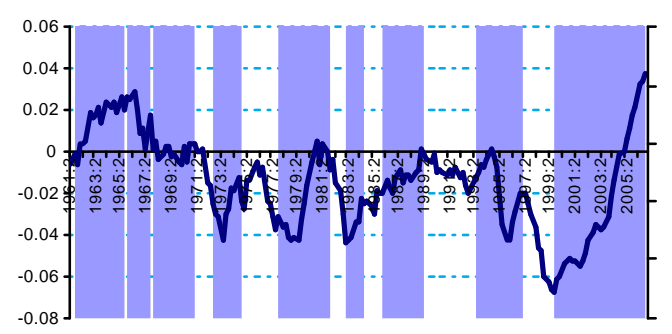

Expansions (SARB) _ Accumulated Response of GDP to Fiscal \& Monetary Shocks

Longer sample (1960+)

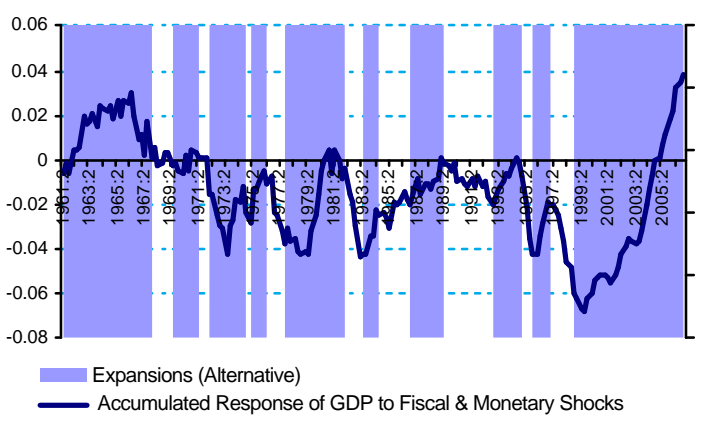

Shorter sample (1983+)

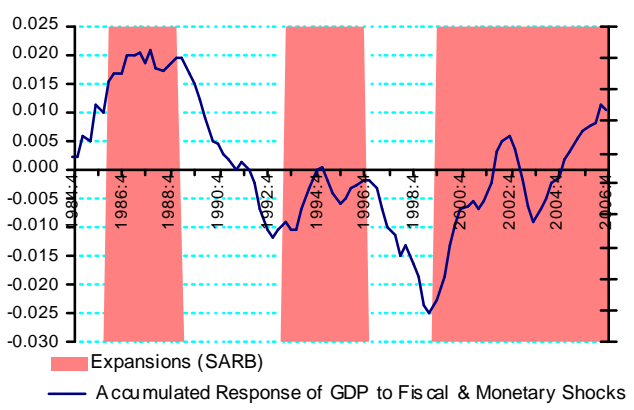

Shorter sample (1983+)

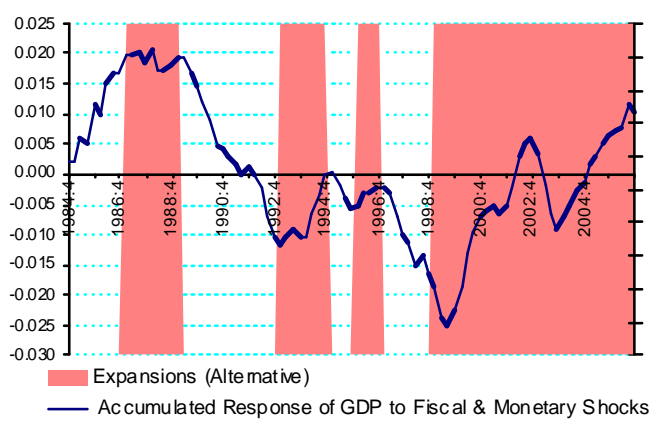




\section{APPENDIX A}

Augmented Dickey-Fuller tests were used to test the null hypothesis of a unit root in the series used here, the results of which are reported in Table 2. There is no evidence of unit roots either in the real GDP differenced series or in the series for real interest rates, but it is not possible to reject the hypothesis of a unit root for the fiscal policy proxy. This raises a concern over the stability of the VAR. Of course, there may be concern over the low power of unit root tests, and thus for a variable such as government expenditure over GDP, it is unlikely to drift forever away from a reasonably stable value. However, to determine how serious this may be, we computed the eigenvalues of the SVAR system. We found that all the eigenvalues lie within the unit circle, and therefore there does not seem to be a risk of VAR instability, despite the unit root test results.

\section{Table 2 U nit root tests}

\begin{tabular}{|c|c|c|c|c|}
\hline \multirow[t]{2}{*}{ Variable } & \multirow[t]{2}{*}{ Sample } & \multicolumn{3}{|c|}{ ADF critical values } \\
\hline & & $\begin{array}{l}\text { No. deterministic } \\
\text { components }\end{array}$ & Constant & $\begin{array}{c}\text { Constant and } \\
\text { trend }\end{array}$ \\
\hline$\Delta \mathrm{y}_{\mathrm{t}}$ & $1960+$ & $-2.691 * * *$ & $-4.656^{* *}$ & $-5.007 * * *$ \\
\hline$\Delta \mathrm{y}_{\mathrm{t}}$ & 1984+ & $-2.155^{* *}$ & $-3.499 * *$ & $-4.339 * * *$ \\
\hline$g_{t}$ & $1960+$ & 1.319 & -1.605 & -1.251 \\
\hline$g_{t}$ & 1984+ & 0.101 & -1.856 & -2.082 \\
\hline $\mathrm{r}_{\mathrm{t}}$ & $1960+$ & $-3.348^{* * *}$ & $-3.874 * * *$ & $-4.438^{* * *}$ \\
\hline$r_{t}$ & $1984+$ & $-2.453^{* *}$ & $-3.336^{* *}$ & $-4.313^{* * *}$ \\
\hline
\end{tabular}

The Augmented Dickey-Fuller statistics were estimated with four lags.

*** Significant at the $1 \%$ level, ** Significant at the 5\% level, * Significant at the $10 \%$ level 


\section{APPENDIX B}

The following table shows the historical decomposition of the South African real GDP for both versions of the SVAR estimated here. Table B.1 shows real GDP, the implied measure of potential GDP and the implied business cycle measure for the model estimated over the longer sample, while table B.2 shows the same for the model estimated over the shorter sample.

Table B.1 H istorical decomposition of real G D P, 1960+ model

\begin{tabular}{|c|c|c|c|c|c|c|c|}
\hline Date & $\begin{array}{l}\text { Real } \\
\text { GDP }\end{array}$ & $\begin{array}{l}\text { Potential } \\
\text { GDP }\end{array}$ & $\begin{array}{l}\text { Output } \\
\text { Gap }\end{array}$ & Date & Real GDP & $\begin{array}{l}\text { Potential } \\
\text { GDP }\end{array}$ & $\begin{array}{l}\text { Output } \\
\text { Gap }\end{array}$ \\
\hline 1961Q1 & 280645 & & & 1984Q1 & 712,246 & 707,749 & 4,497 \\
\hline 1961Q2 & 279418 & 283167 & -3749 & 1984Q2 & 727,042 & 714,400 & 12,642 \\
\hline 1961Q3 & 285659 & 283449 & 2210 & 1984Q3 & 714,992 & 728,019 & $-13,027$ \\
\hline 1961Q4 & 288256 & 290732 & -2476 & 1984Q4 & 716,097 & 714,684 & 1,413 \\
\hline 1962Q1 & 295712 & 292920 & 2792 & 1985Q1 & 711,831 & 714,610 & $-2,779$ \\
\hline 1962Q2 & 297606 & 299595 & -1989 & 1985Q2 & 706,655 & 708,350 & $-1,695$ \\
\hline 1962Q3 & 303416 & 302913 & 503 & 1985Q3 & 704,790 & 706,933 & $-2,143$ \\
\hline $1962 Q 4$ & 307302 & 306557 & 745 & 1985Q4 & 712,326 & 705,216 & 7,110 \\
\hline 1963Q1 & 311367 & 311769 & -402 & 1986Q1 & 703,840 & 708,664 & $-4,824$ \\
\hline $1963 \mathrm{Q} 2$ & 319600 & 317527 & 2073 & 1986Q2 & 708,699 & 706,771 & 1,928 \\
\hline 1963Q3 & 328035 & 325041 & 2994 & 1986Q3 & 710,294 & 706,866 & 3,428 \\
\hline $1963 \mathrm{Q} 4$ & 333815 & 334466 & -651 & 1986Q4 & 713,276 & 712,693 & 583 \\
\hline 1964Q1 & 340068 & 337771 & 2297 & 1987Q1 & 718,464 & 715,712 & 2,752 \\
\hline 1964Q2 & 346223 & 345497 & 726 & 1987Q2 & 721,026 & 718,399 & 2,627 \\
\hline 1964Q3 & 349476 & 350386 & -910 & 1987Q3 & 723,657 & 725,103 & $-1,446$ \\
\hline 1964Q4 & 359695 & 355056 & 4639 & 1987Q4 & 732,541 & 728,796 & 3,745 \\
\hline 1965Q1 & 366616 & 367366 & -750 & 1988Q1 & 743,550 & 739,377 & 4,173 \\
\hline $1965 \mathrm{Q} 2$ & 370162 & 370889 & -727 & 1988Q2 & 748,830 & 749,396 & -566 \\
\hline $1965 \mathrm{Q} 3$ & 368994 & 374783 & -5789 & 1988Q3 & 758,901 & 752,597 & 6,304 \\
\hline $1965 \mathrm{Q} 4$ & 375131 & 373424 & 1707 & 1988Q4 & 766,027 & 763,268 & 2,759 \\
\hline 1966Q1 & 380399 & 380678 & -279 & 1989Q1 & 770,771 & 766,328 & 4,443 \\
\hline $1966 \mathrm{Q} 2$ & 384539 & 385573 & -1034 & 1989Q2 & 774,115 & 772,109 & 2,006 \\
\hline 1966Q3 & 390204 & 389833 & 371 & 1989Q3 & 774,737 & 779,949 & $-5,212$ \\
\hline 1966Q4 & 391488 & 396036 & -4548 & 1989Q4 & 769,943 & 775,540 & $-5,597$ \\
\hline 1967Q1 & 405721 & 399068 & 6653 & 1990Q1 & 770,559 & 769,851 & 708 \\
\hline 1967Q2 & 406366 & 411623 & -5257 & 1990Q2 & 769,923 & 777,447 & $-7,524$ \\
\hline 1967Q3 & 426799 & 414815 & 11984 & 1990Q3 & 769,276 & 770,191 & -915 \\
\hline 1967Q4 & 419050 & 433949 & -14899 & 1990Q4 & 769,990 & 768,754 & 1,236 \\
\hline 1968Q1 & 425930 & 424204 & 1726 & 1991Q1 & 763,866 & 771,276 & $-7,410$ \\
\hline 1968Q2 & 427818 & 432497 & -4679 & 1991Q2 & 762,142 & 762,986 & -844 \\
\hline $1968 \mathrm{Q} 3$ & 432436 & 433126 & -690 & 1991Q3 & 761,846 & 762,718 & -872 \\
\hline 1968Q4 & 440612 & 438117 & 2495 & 1991Q4 & 760,536 & 757,442 & 3,094 \\
\hline 1969Q1 & 443778 & 445886 & -2108 & 1992Q1 & 755,206 & 763,368 & $-8,162$ \\
\hline 1969Q2 & 443404 & 448967 & -5563 & 1992Q2 & 750,574 & 755,680 & $-5,106$ \\
\hline 1969Q3 & 463653 & 453410 & 10243 & 1992Q3 & 741,884 & 751,311 & $-9,427$ \\
\hline 1969Q4 & 457395 & 466872 & -9477 & 1992Q4 & 735,580 & 745,938 & $-10,358$ \\
\hline 1970Q1 & 467240 & 463084 & 4156 & 1993Q1 & 742,097 & 736,393 & 5,704 \\
\hline $1970 \mathrm{Q} 2$ & 476774 & 474001 & 2773 & 1993Q2 & 750,237 & 741,863 & 8,374 \\
\hline 1970Q3 & 471270 & 480793 & -9523 & 1993Q3 & 761,036 & 757,883 & 3,153 \\
\hline
\end{tabular}




\begin{tabular}{|c|c|c|c|c|c|c|c|}
\hline 1970Q4 & 487852 & 478221 & 9631 & 1993Q4 & 766,675 & 764,697 & 1,978 \\
\hline 1971Q1 & 495078 & 495523 & -445 & 1994Q1 & 765,582 & 768,591 & $-3,009$ \\
\hline 1971Q2 & 491042 & 495761 & -4719 & 1994Q2 & 773,888 & 770,962 & 2,926 \\
\hline 1971Q3 & 497438 & 495875 & 1563 & 1994Q3 & 782,592 & 772,707 & 9,885 \\
\hline 1971Q4 & 501,014 & 502,783 & $-1,769$ & 1994Q4 & 795,654 & 791,452 & 4,202 \\
\hline 1972Q1 & 498,060 & 507,077 & $-9,017$ & 1995Q1 & 798,528 & 801,723 & $-3,195$ \\
\hline 1972Q2 & 503,271 & 502,753 & 518 & 1995Q2 & 802,074 & 807,016 & $-4,942$ \\
\hline 1972Q3 & 503,582 & 505,273 & $-1,691$ & 1995Q3 & 805,536 & 815,626 & $-10,090$ \\
\hline 1972Q4 & 512,500 & 509,763 & 2,737 & 1995Q4 & 808,715 & 810,934 & $-2,219$ \\
\hline 1973Q1 & 519,110 & 515,558 & 3,552 & 1996Q1 & 820,063 & 816,103 & 3,960 \\
\hline 1973Q2 & 516,801 & 524,457 & $-7,656$ & 1996Q2 & 835,424 & 827,319 & 8,105 \\
\hline 1973Q3 & 531,747 & 523,353 & 8,394 & 1996Q3 & 844,904 & 841,808 & 3,096 \\
\hline 1973Q4 & 541,990 & 536,596 & 5,394 & 1996Q4 & 852,917 & 848,159 & 4,758 \\
\hline 1974Q1 & 552,117 & 546,061 & 6,056 & 1997Q1 & 855,368 & 859,269 & $-3,901$ \\
\hline 1974Q2 & 559,706 & 557,263 & 2,443 & 1997Q2 & 860,600 & 864,740 & $-4,140$ \\
\hline 1974Q3 & 566,045 & 561,454 & 4,591 & 1997Q3 & 862,397 & 869,707 & $-7,310$ \\
\hline 1974Q4 & 560,702 & 569,544 & $-8,842$ & 1997Q4 & 863,699 & 871,166 & $-7,467$ \\
\hline 1975Q1 & 558,456 & 565,891 & $-7,435$ & 1998Q1 & 864,791 & 871,465 & $-6,674$ \\
\hline 1975Q2 & 568,083 & 560,360 & 7,723 & 1998Q2 & 866,014 & 872,349 & $-6,335$ \\
\hline 1975Q3 & 572,631 & 572,873 & -242 & 1998Q3 & 864,116 & 859,779 & 4,337 \\
\hline 1975Q4 & 577,353 & 576,964 & 389 & 1998Q4 & 864,951 & 873,521 & $-8,570$ \\
\hline 1976Q1 & 584,941 & 580,970 & 3,971 & 1999Q1 & 872,905 & 879,230 & $-6,325$ \\
\hline 1976Q2 & 573,271 & 585,180 & $-11,909$ & 1999Q2 & 879,852 & 883,014 & $-3,162$ \\
\hline 1976Q3 & 586,910 & 578,782 & 8,128 & 1999Q3 & 889,461 & 894,597 & $-5,136$ \\
\hline 1976Q4 & 582,621 & 592,304 & $-9,683$ & 1999Q4 & 899,242 & 895,557 & 3,685 \\
\hline 1977Q1 & 581,348 & 584,227 & $-2,879$ & 2000Q1 & 909,357 & 906,289 & 3,068 \\
\hline 1977Q2 & 581,907 & 584,011 & $-2,104$ & 2000Q2 & 917,724 & 913,835 & 3,889 \\
\hline 1977Q3 & 579,661 & 585,840 & $-6,179$ & 2000Q3 & 926,813 & 924,461 & 2,352 \\
\hline 1977Q4 & 582,638 & 578,689 & 3,949 & 2000Q4 & 934,698 & 935,643 & -945 \\
\hline 1978Q1 & 592,219 & 591,355 & 864 & 2001Q1 & 940,768 & 942,358 & $-1,590$ \\
\hline 1978Q2 & 603,664 & 598,298 & 5,366 & 2001Q2 & 945,471 & 949,205 & $-3,734$ \\
\hline 1978Q3 & 597,170 & 599,191 & $-2,021$ & 2001Q3 & 947,982 & 958,571 & $-10,589$ \\
\hline 1978Q4 & 602,605 & 602,585 & 20 & 2001Q4 & 955,271 & 953,068 & 2,203 \\
\hline 1979Q1 & 613,153 & 607,610 & 5,543 & 2002Q1 & 965,346 & 956,339 & 9,007 \\
\hline 1979Q2 & 617,114 & 618,077 & -963 & 2002Q2 & 977,594 & 968,088 & 9,506 \\
\hline 1979Q3 & 621,720 & 615,392 & 6,328 & 2002Q3 & 988,659 & 981,114 & 7,545 \\
\hline 1979Q4 & 634,479 & 625,926 & 8,553 & 2002Q4 & 996,885 & 993,695 & 3,190 \\
\hline 1980Q1 & 647,514 & 644,735 & 2,779 & 2003Q1 & $1,003,734$ & $1,009,525$ & $-5,791$ \\
\hline 1980Q2 & 659,823 & 649,345 & 10,478 & 2003Q2 & $1,009,319$ & $1,019,042$ & $-9,723$ \\
\hline 1980Q3 & 671,120 & 665,270 & 5,850 & 2003Q3 & $1,015,432$ & $1,021,499$ & $-6,067$ \\
\hline 1980Q4 & 672,628 & 669,836 & 2,792 & 2003Q4 & $1,022,567$ & $1,028,894$ & $-6,327$ \\
\hline 1981Q1 & 680,982 & 684,229 & $-3,247$ & 2004Q1 & $1,037,622$ & $1,029,023$ & 8,599 \\
\hline 1981Q2 & 695,854 & 689,418 & 6,436 & 2004Q2 & $1,054,288$ & $1,046,140$ & 8,148 \\
\hline 1981Q3 & 705,981 & 696,186 & 9,795 & 2004Q3 & $1,072,821$ & $1,068,462$ & 4,359 \\
\hline 1981Q4 & 710,386 & 714,617 & $-4,231$ & 2004Q4 & $1,082,341$ & $1,077,836$ & 4,505 \\
\hline 1982Q1 & 703,805 & 712,172 & $-8,367$ & 2005Q1 & $1,094,907$ & $1,093,412$ & 1,495 \\
\hline 1982Q2 & 697,932 & 706,267 & $-8,335$ & 2005Q2 & $1,109,662$ & $1,107,209$ & 2,453 \\
\hline 1982Q3 & 697,754 & 704,000 & $-6,246$ & 2005Q3 & $1,123,529$ & $1,115,994$ & 7,535 \\
\hline 1982Q4 & 683,003 & 697,937 & $-14,934$ & 2005Q4 & $1,135,402$ & $1,134,710$ & 692 \\
\hline 1983Q1 & 672,461 & 684,804 & $-12,343$ & 2006Q1 & $1,149,336$ & $1,148,473$ & 863 \\
\hline 1983Q2 & 675,253 & 676,992 & $-1,739$ & 2006Q2 & $1,164,856$ & $1,153,124$ & 11,732 \\
\hline 1983Q3 & 683,038 & 679,034 & 4,004 & 2006Q3 & $1,178,196$ & $1,172,574$ & 5,622 \\
\hline 1983Q4 & 700,362 & 689,333 & 11,029 & & & & \\
\hline
\end{tabular}


Table B.2 H istorical decomposition of real G D P, 1983+ model

\begin{tabular}{|c|c|c|c|c|c|c|c|}
\hline Date & $\begin{array}{l}\text { Real } \\
\text { GDP }\end{array}$ & $\begin{array}{l}\text { Potential } \\
\text { GDP }\end{array}$ & $\begin{array}{l}\text { Output } \\
\text { Gap }\end{array}$ & Date & Real GDP & $\begin{array}{l}\text { Potential } \\
\text { GDP }\end{array}$ & $\begin{array}{l}\text { Output } \\
\text { Gap }\end{array}$ \\
\hline 1984Q3 & 714,992 & & & 1995Q4 & 808,715 & 812,648 & $-3,933$ \\
\hline 1984Q4 & 716,097 & 715,862 & 235 & 1996Q1 & 820,063 & 819,265 & 798 \\
\hline 1985Q1 & 711,831 & 711,712 & 119 & 1996Q2 & 835,424 & 831,189 & 4,235 \\
\hline 1985Q2 & 706,655 & 707,126 & -471 & 1996Q3 & 844,904 & 844,840 & 64 \\
\hline 1985Q3 & 704,790 & 703,934 & 856 & 1996Q4 & 852,917 & 852,027 & 890 \\
\hline 1985Q4 & 712,326 & 712,971 & -645 & 1997Q1 & 855,368 & 857,167 & $-1,799$ \\
\hline 1986Q1 & 703,840 & 707,721 & $-3,881$ & 1997Q2 & 860,600 & 862,011 & $-1,411$ \\
\hline 1986Q2 & 708,699 & 706,500 & 2,199 & 1997Q3 & 862,397 & 867,317 & $-4,920$ \\
\hline 1986Q3 & 710,294 & 712,618 & $-2,324$ & 1997Q4 & 863,699 & 869,058 & $-5,359$ \\
\hline 1986Q4 & 713,276 & 715,099 & $-1,823$ & 1998Q1 & 864,791 & 868,182 & $-3,391$ \\
\hline 1987Q1 & 718,464 & 716,748 & 1,716 & 1998Q2 & 866,014 & 869,456 & $-3,442$ \\
\hline 1987Q2 & 721,026 & 722,329 & $-1,303$ & 1998Q3 & 864,116 & 864,621 & -505 \\
\hline 1987Q3 & 723,657 & 727,253 & $-3,596$ & 1998Q4 & 864,951 & 867,599 & $-2,648$ \\
\hline 1987Q4 & 732,541 & 733,319 & -778 & 1999Q1 & 872,905 & 871,124 & 1,781 \\
\hline 1988Q1 & 743,550 & 741,232 & 2,318 & 1999Q2 & 879,852 & 881,271 & $-1,419$ \\
\hline 1988Q2 & 748,830 & 749,096 & -266 & 1999Q3 & 889,461 & 887,406 & 2,055 \\
\hline 1988Q3 & 758,901 & 758,177 & 724 & 1999Q4 & 899,242 & 895,363 & 3,879 \\
\hline 1988Q4 & 766,027 & 762,934 & 3,093 & 2000Q1 & 909,357 & 902,938 & 6,419 \\
\hline 1989Q1 & 770,771 & 768,964 & 1,807 & 2000Q2 & 917,724 & 913,121 & 4,603 \\
\hline 1989Q2 & 774,115 & 772,880 & 1,235 & 2000Q3 & 926,813 & 924,856 & 1,957 \\
\hline 1989Q3 & 774,737 & 772,693 & 2,044 & 2000Q4 & 934,698 & 932,912 & 1,786 \\
\hline 1989Q4 & 769,943 & 769,680 & 263 & 2001Q1 & 940,768 & 940,219 & 549 \\
\hline 1990Q1 & 770,559 & 766,905 & 3,654 & 2001Q2 & 945,471 & 943,960 & 1,511 \\
\hline 1990Q2 & 769,923 & 770,718 & -795 & 2001Q3 & 947,982 & 949,437 & $-1,455$ \\
\hline 1990Q3 & 769,276 & 771,874 & $-2,598$ & 2001Q4 & 955,271 & 953,100 & 2,171 \\
\hline 1990Q4 & 769,990 & 768,419 & 1,571 & 2002Q1 & 965,346 & 964,053 & 1,293 \\
\hline 1991Q1 & 763,866 & 762,680 & 1,186 & 2002Q2 & 977,594 & 976,058 & 1,536 \\
\hline 1991Q2 & 762,142 & 758,672 & 3,470 & 2002Q3 & 988,659 & 990,264 & $-1,605$ \\
\hline 1991Q3 & 761,846 & 760,235 & 1,611 & 2002Q4 & 996,885 & $1,000,712$ & $-3,827$ \\
\hline 1991Q4 & 760,536 & 759,002 & 1,534 & 2003Q1 & $1,003,734$ & $1,006,929$ & $-3,195$ \\
\hline 1992Q1 & 755,206 & 758,851 & $-3,645$ & 2003Q2 & $1,009,319$ & $1,015,263$ & $-5,944$ \\
\hline 1992Q2 & 750,574 & 752,041 & $-1,467$ & 2003Q3 & $1,015,432$ & $1,018,659$ & $-3,227$ \\
\hline $1992 \mathrm{Q} 3$ & 741,884 & 745,823 & $-3,939$ & 2003Q4 & $1,022,567$ & $1,022,961$ & -394 \\
\hline 1992Q4 & 735,580 & 737,725 & $-2,145$ & 2004Q1 & $1,037,622$ & $1,033,262$ & 4,360 \\
\hline 1993Q1 & 742,097 & 738,799 & 3,298 & $2004 \mathrm{Q} 2$ & $1,054,288$ & $1,049,575$ & 4,713 \\
\hline 1993Q2 & 750,237 & 743,953 & 6,284 & 2004Q3 & $1,072,821$ & $1,069,526$ & 3,295 \\
\hline 1993Q3 & 761,036 & 758,532 & 2,504 & 2004Q4 & $1,082,341$ & $1,080,983$ & 1,358 \\
\hline $1993 Q 4$ & 766,675 & 766,010 & 665 & 2005Q1 & $1,094,907$ & $1,093,305$ & 1,602 \\
\hline 1994Q1 & 765,582 & 767,155 & $-1,573$ & 2005Q2 & $1,109,662$ & $1,107,435$ & 2,227 \\
\hline 1994Q2 & 773,888 & 773,555 & 333 & 2005Q3 & $1,123,529$ & $1,120,809$ & 2,720 \\
\hline 1994Q3 & 782,592 & 781,234 & 1,358 & 2005Q4 & $1,135,402$ & $1,133,819$ & 1,583 \\
\hline 1994Q4 & 795,654 & 795,213 & 441 & 2006Q1 & $1,149,336$ & $1,150,461$ & $-1,125$ \\
\hline 1995Q1 & 798,528 & 801,598 & $-3,070$ & 2006Q2 & $1,164,856$ & $1,162,177$ & 2,679 \\
\hline 1995Q2 & 802,074 & 807,906 & $-5,832$ & 2006Q3 & $1,178,196$ & $1,176,693$ & 1,503 \\
\hline 1995Q3 & 805,536 & 810,112 & $-4,576$ & & & & \\
\hline
\end{tabular}




\section{REFERENCES}

Akinboade, O. A. (2005). "Some estimates of potential output and the output gap for South Africa." Journal for Studies in Economics and Econometrics, 29(1): 15-28.

Arora, V. and A. Bhundia (2003). Potential Output and Total Factor Productivity Growth in Post-Apartheid South Africa. Washington, IMF working paper:

WP/03/178.

Blanchard, O. J. and D. Quah (1989). "The Dynamic Effects of Aggregate Demand and Supply Disturbances." American Economic Review, 79(4): 655-673.

Burger, P. and M. Marinkov (2006). "The South African Phillips curve: how applicable is the Gordon model?" South African Journal of Economics, 74(2): 172-189.

Clarida, R. and J. Galí (1994). "Sources of Real Exchange Rate Fluctuations: How Important are nominal Shocks?" Carnegie-Rochester Conference Series on Public Policy, 41: 1-56.

De Jager, B. and D. Smal (1984). "Potential Gross Domestic Product of South Africa." South African Reserve Bank Quarterly Bulletin, 154: 59-79.

De Kock Commission (1985). Final report of the commission of inquiry into the monetary system and monetary policy in South Africa (RP 70/1984). Pretoria, Governm ent Printer.

Du Plessis, S. A. (2006). "Reconsidering the business cycle and stabilisation policies in South Africa." Economic Modelling, 23(5): 761-774.

Du Plessis, S. A. and B. W. Smit (2007). "Countercyclical Monetary Policy in South Africa." Lournal for Studies in Economics and Econometrics, 31(1): 79-98.

Du Toit, C. B. and E. Moolman (2003). "Estimating potential output and capacity utilization for the South African economy." South African Journal of Economics, 71(1): 96-118.

Du Toit, C. B., R. Van Eyden and M. Ground (2006). Does South Africa have the potential and capacity to grow at 7 per cent: A labour market perspective. Pretoria, Department of Economics Working Paper Series No 2006-03, University of Pretoria.

DuPasquier, C., A. Guay and P. St-Amant (1999). "A Survey of Alternative Methodologies for Estimating Potential Output and the Output Gap." Lournal of Macroeconomics, 21(3): 577-595.

Fatás, A. and I. Mihov (2003). "The case for restricting fiscal policy discretion." Quarterly Journal of Economics, 2003(November): 1419-1447. 
Fedderke, J. W. and E. Schaling (2005). "Modelling inflation in South Africa: a multivariate cointegation analysis." South African Journal of Economics, 73(1): 79-92.

Feinstein, C. H. (2005). An economic history of South Africa: Conquest, discrimination and development. Cambridge, Cambridge University Press.

Frankel, J., B. W. Smit and F. Sturzenegger (2007). South Africa: Macroeconomic Challenges after a Decade of Success. Cambridge MA, CID Working Paper No. 133, April 2007.

Galí, J. (1992). "How Well Does the IS-LM Model Fit U.S. Data?" Quarterly Journal of Economics, 107(May): 709-738.

Geldenhuys, J. P. and M. Marinkov (2006). Robust estimates of Oken's Coefficient for South Africa, DPRU Conference Paper, October 2006.

Kaseeram, I., T. Nichola and S. Mainardi (2004). "South African inflationary dynamics and the pass-through effects from depreciation to unit labour costs." South African Journal of Economics, 72(1): 85-107.

King, R. G., C. I. Plosser, J. H. Stock and M. W. Watson (1991). "Stochastic Trends and Economic Fluctuations." American Economic Review, 81(4): 819-840.

Knedlik, T. (2006). "Estimating monetary policy rules for South Africa." South African Lournal of Economics, 74(4): 629-641.

Moll, T. (1991). "Did the apartheid economy 'fail'?" Journal of Southern African Studies, 17(2): 271-291.

Shapiro, M. D. and M. W. Watson (1988). Sources of Business Cycles Fluctuations. In: S. Fischer (eds.). NBER Macroeconomics Annual, The MIT Press. 1988.

Smit, B. W. and L. Burrows (2002). Estimating potential output and output gaps for the South African economy. Stellenbosch, Stellenbosch Economic Working Paper, No 5/2002, Stellenbosch University.

Woglom, G. (2005). "Forecasting South African inflation." South African Journal of Economics, $73(2):$ 302-320. 